\title{
PENERAPAN TERAPI PERILAKU KOGNITIF DALAM MENINGKATKAN AKTIVITAS BELAJAR ANAK DI KOTA BANDUNG
}

\author{
Sofie Herawati*, Tuti Kartika, dan Uke Hani Rasalwati \\ Sekolah Tinggi Kesejahteraan Sosial Bandung \\ E-mail: sofiehera@ymail.com
}

\begin{abstract}
This research aims to examine and analyze the application of cognitive behavioral therapy that can improve learning activities "YS". Type of learning activities that became the focus of research is oral activity. The aspect in this oral activity is related to the behavior of memorizing juz'ama. The use of cognitive behavioral therapy is an attempt to change the cognition and behavior of "YS" to be a positive thing. The research approach used is quantitative research using Single Subject Design. The research model used is ABA model consisting of three phases, among others (a) Phase Al (baseline) (b) Phase B (intervention), and (c) Phase A2 (outcome). The instrument used is a record of observation of behavioral observation. Data collection techniques used include observation, interviews, documentation studies, and permanent product recording. The results showed that the application of effective cognitive behavioral therapy to change cognition and improve the behavior of memorizing juz'ama "YS". Increasing the behavior of memorizing juz'ama is seen from aspects of the memorization, the frequency of memorization, and the number of verses that are memorized.
\end{abstract}

Keywords: Cognitive Behavior Therapy, learning activity, memorize behavior

Abstrak

Penelitian ini bertujuan untuk mengkaji dan menganalisis penerapan terapi perilaku kognitif yang dapat meningkatkan aktivitas belajar "YS". Jenis aktivitas belajar yang menjadi fokus penelitian yaitu aktivitas oral. Aspek dalam aktivitas oral ini terkait dengan perilaku menghafal juz'ama. Penggunaan terapi perilaku kognitif ini merupakan upaya untuk mengubah kognisi dan perilaku "YS" menjadi hal yang positif. Pendekatan penelitian yang digunakan yaitu penelitian kuantitatif dengan menggunakan Desain Subjek Tunggal. Model penelitian yang digunakan yaitu model ABA yang terdiri dari tiga fase antara lain (a) Fase A1 (baseline) (b) Fase B (intervensi), dan (c) Fase A2 (hasil). Instrumen yang digunakan adalah lembar pencatatan obervasi perilaku. Teknik pengumpulan data yang digunakan antara lain observasi, wawancara, studi dokumentasi, dan pencatatan produk permanen. Hasil penelitian menunjukkan bahwa penerapan terapi perilaku kognitif efektif untuk mengubah kognisi dan meningkatkan perilaku menghafal juz'ama "YS". Meningkatnya perilaku menghafal juz'ama ini dilihat dari aspek durasi menghafal, frekuensi menghafal, dan jumlah ayat yang dihafal.

Kata kunci: aktivitas belajar, perilaku menghafal, Terapi Perilaku Kognitif 


\section{Pendahuluan}

Keterlantaran anak merupakan salah satu bentuk kegagalan pengasuh untuk memenuhi kebutuhan dasar anak, memungkinkan anak terampas atau kehilangan kebutuhan fisik, emosional, medis, kesehatan mental, atau kebutuhan pendidikan (Zastrow dan Karen; 2007). Menurut Zastrow dan Karen (2007) menyatakan bahwa kasus katerlantaran anak terjadi pada saat anak-anak tidak diberikan apa yang mereka butuhkan untuk bertahan hidup dan berkembang.

Dua aspek yang paling sering diabaikan sehingga anak mengalami keterlantaran yaitu aspek fisik dan pengawasan yang tidak memadai. Keterlantaran fisik dapat berupa tidak terpenuhinya kebutuhan anak yang berkaitan dengan tempat tinggal, makanan dan pakaian. Sedangkan pengawasan yang tidak memadai lebih cenderung pada situasi dimana anak tanpa pengasuh atau didampingi oleh pengasuh yang lalai sehingga anak berada dalam ancaman yang dapat membahayakan keselamatannya

Anak terlantar merupakan anak yang tidak terpenuhi kebutuhan dasarnya baik disengaja maupun tidak sengaja oleh orangtuanya (Undang-Undang Nomor 35 Tahun 2014). Batasan usia dalam konteks anak terlantar ini yaitu mencapai 6 sampai 18 tahun. Bahkan dalam suatu kondisi anak dapat kehilangan pengasuhan orangtua secara langsung dikarenakan ketidakmampuan orangtua dalam melaksanakan peranannya atau terjadi penolakan peran orangtua dalam mendidik anaknya.

Dampak yang sering terjadi pada kasus anak yang mengalami keterlantaran yaitu berisiko untuk mendapatkan tindakan kekerasan, eksploitasi, diskriminasi, dan perlakuan salah dari orangtua atau orang-orang terdekat anak. Faktor penyebab yang timbul dari anak yang mengalami keterlantaran antara lain stress dan frustasi tingkat individu yang berasal dari lingkungan sosial dan keluarga, pengalaman pengasuhan yang diperoleh orangtua di masa lalu, latar belakang pendidikan yang rendah, status anak di keluarga yang diidentikkan sebagai makhluk yang belum memiliki kematangan berpikir, kelahiran anak yang tidak diinginkan, serta ekspektasi orangtua yang tinggi terhadap anak.

Kasus anak yang mengalami keterlantaran kurang memperoleh perhatian publik secara serius dibandingkan kasus tindak kekerasan anak yang mengakibatkan penderitaan baik secara fisik dan psikis. Hal ini dikarenakan kasus keterlantaran anak dianggap sebagai masalah intern yang terjadi pada keluarga sehingga sulit untuk diakses dan dilakukan penanganan tanpa adanya kesadaran dari pihak keluarga. Padahal munculnya masalah sosial anak lainnya seperti kekerasan, eksploitasi, perlakuan salah, dan diksriminasi berawal dari anak yang ditelantarkan oleh orangtuanya baik secara sengaja maupun tidak sengaja.

Cara efektif untuk menghadapi beragam kasus anak yaitu diperlukan keterlibatan dan kepedulian berbagai pihak untuk menangani masalah tersebut secara tepat dan holistik. Hal ini dikarenakan jumlah persebaran kasus anak terlantar semakin marak dan meningkat baik yang ada di tingkat kabupaten/kota maupun provinsi. Bahkan kasus ini mencuat menjadi kasus nasional dan dasar terjadinya beragam bentuk tindak kekerasan dari orang-orang terdekat anak, sehingga perlu mendapatkan perhatian dan penanganan bersama.

Jumlah anak terlantar setiap tahunnya mengalami peningkatan baik itu di tingkat Provinsi maupun Kota. Data rekapitulasi anak terlantar tahun 2011 di Jawa Barat berjumlah 126.243 jiwa sedangkan pada tahun 2012 menunjukkan angka 128.045 jiwa yang tersebar di 17 Kabupaten dan 9 Kota. Salah satunya Kota Bandung (diakses dari www.perwakilan.jabarprov.go.id dan www.dissos.jabarprov.go.id). Menurut data yang diperoleh dari Portal Bandung Tahun 2010, menunjukkan bahwa jumlah anak terlantar sebanyak 6.643 jiwa dan tahun 2012 berjumlah 5.848 jiwa. Data tersebut menunjukkan bahwa masalah anak terlantar 
mengalami penurunan sekitar $12 \%$ dalam jangka waktu dua tahun. Penurunan jumlah anak terlantar ini tidak terlepas dari peranan Pemerintah Kota dalam menyelenggarakan berbagai program penanganan dan menggerakan semua elemen yang terkait. Jumlah anak terlantar tahun 2013 yang telah terjangkau melalui program pembinaan anak terlantar sebanyak 6.643 jiwa. Dana yang dicanangkan untuk pelaksanaan program tersebut tidak hanya terfokus dari APBD tetapi juga merupakan anggaran Provinsi dan Negara.

Melihat fenomena tersebut, masalah anak terlantar menjadi isu sosial yang sering terjadi di kalangan masyarakat miskin dan padat penduduk. Oleh karena itu, hal ini perlu mendapatkan perhatian serius dan penanganan melalui model layanan secara integratif. Tujuannya agar anak mendapatkan layanan yang tepat dan sesuai dengan kebutuhannya. Model penanganan integratif ini tidak hanya menyentuh masalah yang terjadi pada diri anak secara personal, namun mencakup sistem ekologi anak.

Selain itu juga, penanganan anak terlantar ini memerlukan adanya keterlibatan langsung profesi pekerja sosial anak sebagai orang yang terlatih dan terdidik secara profesional. Pelayanan yang diberikan oleh pekerja sosial anak bagi anak-anak yang mengalami keterlantaran menjadi hal yang paling primer, tujuannya agar anak dapat kembali berfungsi secara psikis, sosial, dan fisiknya. Profesi pekerja sosial anak ini harus dibekali dengan kemampuan dan kompetensi dalam bidang penanganan masalah anak yang diperolehnya melalui pelatihan atau pendidikan formal di perguruan tinggi. Selain itu, keterlibatan dan kerjasama aktif dari berbagai multidisipliner dan instansi terkait mempermudah pekerja sosial untuk memperoleh akses layanan yang diperlukan anak dan keluarga secara tepat dan berkelanjutan.

Kegiatan awal penelitian menjadi salah satu cara peneliti dalam menangani masalah anak terlantar yang terjadi di suatu wilayah atau institusi dengan menggunakan pendekatan praktik pekerjaan sosial integratif yang mencakup aras makro, mikro, dan mezo. Penelitian ini dilakukan selama empat bulan sejak Bulan Juli sampai dengan Bulan November 2016 pada setting masyarakat, tepatnya di RW 09 Kelurahan Cipadung Kecamatan Cibiru Kota Bandung. Kondisi keterlantaran yang terjadi di RW 09 lebih mengarah pada penerapan pola pengasuhan orangtua yang kurang tepat, hilangnya pemenuhan kebutuhan emosional anak, dan kontrol masyarakat dan orangtua yang tidak memadai Kondisi tersebut berdampak pada hilangnya peranan orangtua, keluarga, dan masyarakat dalam melindungi dan merawat anak dengan baik.

Kondisi keterlantaran anak tersebut dipengaruhi oleh beragam faktor baik yang berasal dari internal (lingkungan keluarga) maupun eksternal. Faktor internal lebih mengarah pada pendapatan keluarga yang tidak memadai, latar pendidikan orangtua yang rendah, status pekerjaan yang tidak menentu, pengalaman buruk orangtua di masa lalu, kondisi tempat tinggal yang tidak layak huni, serta pola pengasuhan buruk yang diterapkan orangtua dalam mendidik anak-anaknya. Sedangkan faktor eksternal lebih dipengaruhi oleh kondisi pemukiman yang padat penduduk, status pendidikan dan penghasilan masyarakat yang rendah, tradisi masyarakat dalam membesarkan anak-anaknya, serta peralihan fungsi dan peranan wanita menjadi sebagai tulang punggung keluarga.

Isu prioritas yang terjadi pada anak terlantar yaitu terkait dengan pendidikan, dimana banyak orangtua RW bersikap tidak peduli dan acuh terhadap pendidikan anak, mereka menganggap bahwa pendidikan bukan menjadi kebutuhan utama anak untuk tumbuh dan berkembang. Hal ini berdampak pada cara pandang dan perilaku anak dalam memahami arti sekolah bagi keberlangsungan masa depannya.

Orangtua menganggap bahwa pendidikan anak bukan menjadi kebutuhan utama untuk menunjang proses tumbuh kembangnya. Begitu 
juga, pendidikan sebagai media untuk membentuk karakter kepribadian anak yang

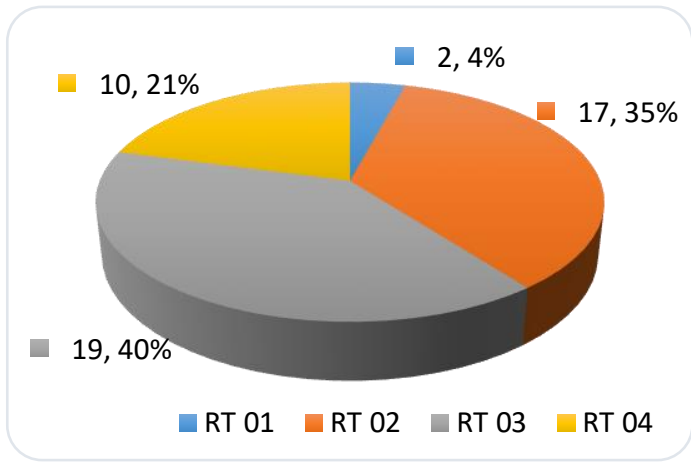

Gambar 1

Data Persebaran Anak Terlantar di RW 09 Kelurahan Cipadung

lebih baik serta tempat kedua anak untuk bersosialisasi dengan teman-temannya. Bahkan pendidikan juga bisa menjadi salah satu perantara untuk mengubah kognisi, sikap, dan perilaku anak dalam menentukan masa depannya secara terorganisir dan bertujuan. Minimnya peran orangtua dalam mendukung proses kegiatan belajar serta sikap acuh orangtua dalam mengontrol aktivitas anak di luar rumah, berdampak pada seringnya muncul masalah anak yang mengalami hambatan/kesulitan dalam melakukan aktivitas belajar baik di sekolah maupun di rumah.

Data jumlah anak terlantar yang diperoleh peneliti berdasarkan hasil penjangkauan di RW 09 sebanyak 48 anak yang tersebar di empat RT. Rentang usia anak terlantar yaitu dari 6 tahun sampai 18 tahun. (lihat Gambar 1). Berdasarkan data tersebut, peneliti melakukan penelusuran untuk menemukan lima subjek anak terlantar yang mengalami masalah pendidikan. Kelima subjek tersebut menjadi kelompok sasaran praktik pekerjaan sosial dengan menggunakan pendekatan mikro.

Berdasarkan data persebaran anak terlantar tersebut, tingkatan pendidikan anak terlantar yang ada di RW 09 dikategorikan menjadi empat bagian yaitu pendidikan usia dini, SD, SMP, dan SMA. Selain itu, anak terlantar yang ada di RW 09 juga ada yang mengalami putus sekolah sejak SD dan SMP. Gambar 2 menunjukkan bahwa anak terlantar di RW 09 yang menjalankan pendidikan Sekolah Dasar (SD) lebih tinggi dibandingkan dengan anakanak yang duduk di bangku pendidikan lainnya yaitu berjumlah 20 jiwa atau 41,67\%.

Kondisi aktivitas belajar anak yang mengeyam pendidikan Sekolah Dasar (SD) di RW 09 cenderung mengkhawatirkan. Hal ini didukung oleh beberapa faktor baik yang berasal dari diri anak, keluarga, dan lingkungan tempat tinggalnya. Anak-anak RW 09 lebih tertarik untuk bermain dengan teman-teman di lingkungan sekitar tempat tinggalnya, sehingga tidak jarang anak-anak yang berusia sekolah dasar masih banyak yang belum bisa membaca dan berhitung secara cepat sesuai dengan tingkatan kelasnya. Kegiatan bermain menjadi prioritas utama bagi anak untuk mendapatkan kenyamanan dan kesenangan, hal ini juga dijadikan sebagai ajang untuk mengatasi kejenuhan pascabelajar di sekolah.

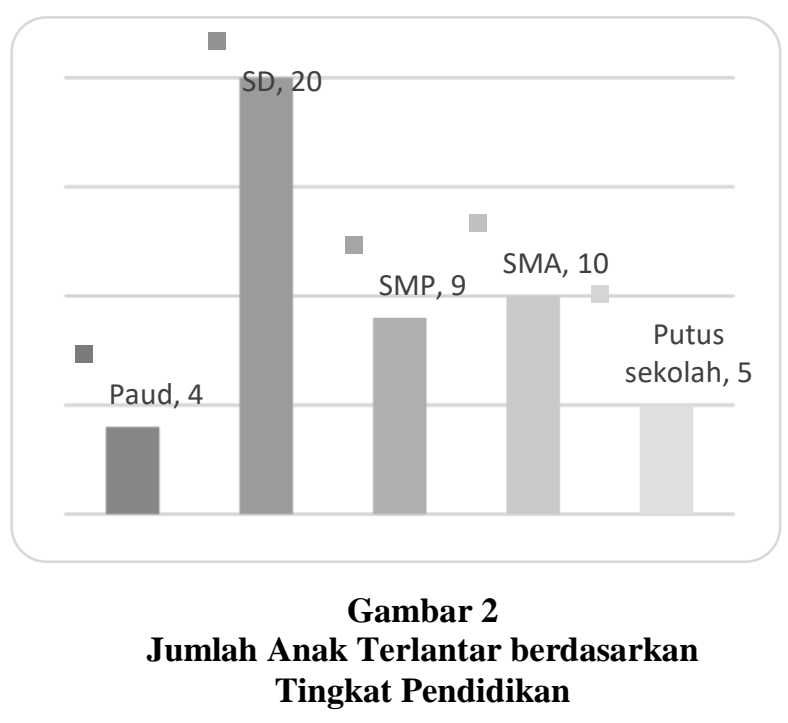

Hambatan belajar yang dihadapi anak membuat anak bersikap putus asa/pasrah dalam menghadapi masalah tersebut, kehilangan semangat dan minat belajar anak di rumah atau sekolah, serta pandangan bahwa kekurangan yang dimilikinya tidak dapat berubah. Ketidakmampuan anak dalam beradaptasi dengan beragam aktivitas belajar anak di sekolah, berpengaruh besar terhadap prestasi belajar anak di kelas, sehingga kerap terjadi anak yang tertinggal kelas atau anak yang memilih untuk tidak melanjutkan sekolah. 
Fenomena tersebut diperkuat oleh kondisi latar belakang keluarga, dimana orangtua yang memiliki pendidikan rendah kurang begitu paham tentang pentingnya pendidikan sehingga seringkali orangtua membiarkan anaknya untuk tidak masuk sekolah, tidak mengerjakan tugas, dan tidak belajar pada saat menghadapi ujian. Bahkan orangtua tidak peduli dengan hambatan belajar yang dihadapi anak, orangtua jarang mendampingi dan membimbing aktivitas belajar anak di rumah.

Cara orangtua dalam menghadapi masalah belajar anak ditanggapi dengan sikap pasrah dan acuh sehingga mereka memiliki keyakinan bahwa masalah yang terjadi pada anaknya tidak dapat dirubah. Hal ini dikarenakan orangtua melihat perilaku anaknya yang tidak mau dibimbing dan belajar di rumah. Pengaruh lingkungan pertemanan anak juga, ikut memperburuk kondisi yang sedang terjadi pada diri anak. Jadwal kegiatan bermain yang tanpa batas membuat anak melupakan tugas dan kewajibannya sebagai pelajar

Kondisi anak yang bersekolah di tingkat menengah dan atas cenderung berisiko untuk mengalami putus sekolah. Hal ini dikarenakan anak-anak yang tergolong remaja lebih didominasi oleh pergaulan di luar rumah. Mereka telah banyak terpengaruh oleh keberadaan komunitas-komunitas anak-anak funk remaja yang tersebar di wilayah Cibiru. Keberadaan komunitas-komunitas tersebut membuat anak tertarik untuk bergabung sehingga mereka lebih mementingkan berkumpul daripada belajar di rumah.

Mayoritas dari mereka lebih memilih untuk tidak masuk sekolah demi menghadiri acaraacara dalam komunitas remaja hingga larut malam seperti komunitas anak-anak funk, komunitas band, komunitas kesenian, komunitas pecinta bola, komunitas pecinta geng motor. Komunitas anak remaja ini membuat mereka merasa nyaman dan senang sehingga tidak menyadari bahwa mereka memiliki tugas sekolah yang harus diselesaikan keesokan harinya. Kebiasaan anak remaja tersebut menjadikannya tidak bersemangat untuk mengikuti aktivitas belajar mengajar dengan baik di sekolah dan memilih untuk berhenti sekolah.

Faktor lainnyapun ikut serta mendominasi terhadap keberlanjutan pendidikan anak seperti kondisi perekonomian keluarga. Kondisi ekonomi keluarga yang berada pada tingkatan kelas menengah ke bawah menjadi salah satu faktor anak mengalami putus sekolah. Faktor lingkungan dan budaya masyarakat yang menganggap bahwa pendidikan bukan merupakan kebutuhan utama bagi masa depan anak sehingga masyarakat bersikap acuh terhadap anak-anak yang mengalami masalah belajar di sekolah, begitu juga dengan anak yang kehilangan semangat belajar.

Penggabungan beberapa faktor yang berasal dari internal anak, keluarga, masyarakat, dan kondisi lingkungan tempat tinggal tersebut memperkuat bahwa masalah pendidikan kerap terjadi pada anak-anak RW 09. Situasi buruk yang terjadi pada anak sebagaimana penjelasan di atas, menyebabkan terganggunya proses aktivitas belajar yang berdampak pada hilangnya minat untuk membaca, menghafal, dan mengerjakan tugas-tugas sekolahnya di rumah.

Pada saat kegiatan penelitian berlangsung, peneliti menangani kasus anak terlantar yang berjumlah lima subjek terdiri dari subjek "LN", subjek "RR", subjek "YS", subjek "IH", dan subjek "DG". Hasil penelitian menunjukkan bahwa kelima subjek tersebut meliputi "LN" (Pr, 15 tahun) terindikasi mengalami perilaku tidak masuk sekolah, "RR" (Lk, 9 tahun) mengalami hambatan dalam melakukan aktivitas belajar, "YS" (Lk, 13 tahun) mengalami masalah perilaku tidak masuk sekolah dan begadang, "IH" (Lk, 9 tahun) mengalami hambatan dalam melakukan aktivitas belajar seperti membaca, menghafal, dan berhitung, serta "DG" (Lk, 13 tahun) mengalami masalah kepercayaan diri yang rendah. Kelima kasus yang dialami oleh masing-masing subjek di atas, ditangani melalui serangkaian kegiatan intervensi dengan 
menggunakan teknik pengubahan perilaku seperti token ekonomi dan penguatan positif.

Pasca intervensi, subjek "LN", "RR", "IH" dan "DG" menunjukkan perubahan perilaku sesuai dengan tujuan intervensi meskipun belum menunjukkan hasil yang maksimal. Keempat subjek tersebut diberikan intervensi dengan menggunakan teknik pengubahan perilaku yang melibatkan orang-orang terdekat subjek seperti keluarga. Intervensi yang dilakukan peneliti untuk menangani masalah subjek "RR" yaitu menggunakan token ekonomi. Hasil intervensi menunjukkan bahwa teknik ini mampu merangsang minat belajar subjek "RR" agar mau mengerjakan tugas matematikanya dengan dampingan ibu kandungnya.

Intervensi yang diterapkan peneliti untuk menangani masalah subjek "LN" yaitu dengan menggunakan teknik penguatan positif. Perubahan yang dicapai pascaintervensi, subjek "LN" kembali bersekolah pada saat hafalan juz'ama sehingga meminimalisir keinginannya untuk pindah sekolah. Sedangkan intervensi yang digunakan untuk menangani masalah subjek "DG" dilakukan melalui penggunaan teknik penguatan positif. Hasil intervensi menunjukkan perubahan perilaku pada diri subjek, dimana keberanianya untuk tampil di depan kelas bersama temannya muncul secara bertahap. Subjek "DG" juga berani menjawab pertanyaan yang disampaikan oleh guru mata pelajaran matematika.

Selanjutnya, intervensi yang diterapkan pada subjek "IH" yaitu dengan menggunakan teknik penguatan positif. Pascaintervensi, subjek "IH" menunjukkan perubahan perilaku dimana ia mau belajar menghafal huruf abjad, mengeja huruf menjadi rangkaian kata dan menuliskan identitas diri. Namun kegiatan belajar ini perlu didampingi dan dibimbing langsung oleh orangtua "IH" atau peneliti. Keberhasilan perubahan perilaku yang terjadi pada keempat subjek pascaintervensi merupakan hasil kerjasama yang baik antara orangtua dan peneliti serta dukungan orang-orang terdekat subjek. Namun, berbeda dengan kasus yang terjadi pada subjek "YS", penerapan intervensi yang dilakukan melalui teknik pengubahan perilaku belum menunjukkan hasil dan perubahan maksimal, meskipun orangtua turut andil dalam memberikan dukungan selama pelaksanaan intervensi berlangsung agar anaknya dapat mengikuti aktivitas belajar di sekolah dengan baik.

Penerapan teknik penguatan positif pada subjek "YS" tersebut belum efektif untuk mengatasi masalah aktivitas belajar anak baik di sekolah atau di rumah. Hal ini dipengaruhi oleh faktor internal dan lingkungan pertemanan subjek "YS" yang kuat. Subjek "YS" merasa bahwa situasi rumah tidak dapat memberikan kenyamanan bagi dirinya sehingga dia lebih memilih untuk menghabiskan sebagian waktunya bersama dengan teman-temannya. Begitu juga dengan pola pikir yang dimiliki subjek "YS" bahwa lingkungan pertemanan lebih dapat memberikan kesenangan dan kenyamanan dibandingkan dengan kegiatan belajar. Pengaruh pola pikir yang dimiliki subjek "YS" ini tentunya berpengaruh terhadap perilaku yang bertentangan dengan harapan orangtuanya.

Kondisi psikologis subjek "YS" yang tidak stabil juga ikut mempengaruhi emosi/perasaannya untuk tidak melakukan kegiatan belajar di rumah, seperti subjek "YS" yang merasa jenuh, bosan dan putus asa pada saat menghadapi kesulitan belajar. Subjek "YS" memiliki hambatan dalam menuntaskan tugas hafalan di sekolah, tugas hafalan ini biasanya berkaitan dengan mata pelajaran islam seperti juz'ama, qur'an hadist, fiqih, bahasa arab, dan sejarah kebudayaan islam.

Kesulitan "YS" dalam menghafal dipengaruhi oleh cara pandang "YS" yang mengganggap bahwa hafalan itu sulit dan membosankan sehingga ia kerapkali menyimpulkan bahwa kekurangan yang dimiliki tersebut tidak dapat diubah oleh "YS". Namun, menurut penuturan "YS" bahwa tugas hafalan yang setiap hari wajib disetorkan kepada guru yang bersangkutan yaitu materi juz'ama. Mata pelajaran juz'ama ini termasuik mata pelajaran 
yang wajib dihafalkan oleh semua siswa sebagai syarat kelulusan.

Materi juz'ama yang dihafalkan oleh siswa tersebut disesuaikan dengan tingkatan kelas, misal "YS" duduk di bangku kelas 5 mendapatkan tugas hafalan surat At-Takwir, Al-Infithar, dan surat Al-Muthafifin. Berdasarkan gambaran kasus diatas, intervensi yang dilakukan peneliti pada saat penelitian yaitu dengan menggunakan teknik penguatan positif. Hasil yang diperoleh melalui intervensi ini belum menunjukkan perubahan yang maksimal.

Perubahan yang terjadi pada subjek YS yaitu subjek mampu mengurangi frekuensi begadang bersama teman-temannya terkecuali di hari libur sekolah. Penerapan teknik penguatan positif ini tidak sepenuhnya dapat mengubah perilaku dan cara berpikir "YS" terhadap aktivitas belajar sebagaimana yang telah disepakati bersama pada saat perencanaan intervensi. Berdasarkan penjelasan di atas, peneliti mempertimbang bahwa subjek "YS: perlu mendapatkan intervensi dengan menggunakan pendekatan lain agar keadaanya tidak semakin memburuk atau memunculkan perilaku negatif lainnya.

Pendekatan yang digunakan oleh peneliti untuk menangani kasus subjek "YS" yaitu dengan menggunakan pendekatan terapi perilaku kogntif. Menurut Sheldon (2005) terapi perilaku kognitif adalah terapi yang digunakan untuk mengurangi perilaku yang tidak sesuai dan meningkatkan perilaku yang sesuai. Caranya dengan mengubah kognisi seseorang. Perubahan kognisi yang positif diharapkan dapat mendorong terjadinya perilaku yang positif. Terapi ini merupakan intervensi lanjutan dikarenakan masih ada hal-hal tertentu yang belum terselesaikan, seperti akar permasalahan yang menyebabkan "YS" berperilaku tidak masuk sekolah atau bolos sekolah. Selain perilaku begadang yang menyebabkan "YS" tidak masuk sekolah, ternyata "hambatan atau kesulitan "YS" dalam menghafal juz'ama juga menjadi pemicu subjek untuk tidak masuk sekolah atau bolos sekolah. Untuk meningkatkan perilaku menghafal juz'ama subjek "YS", peneliti meggunakan pendekatan terapi perilaku kogntif.

Pendekatan terapi perilaku kognitif menggabungkan antara teknik yang digunakan untuk mengubah cara berpikir "YS" terhadap suatu situasi dan terapi perilaku. Untuk mengubah kognisi "YS", peneliti menggunakan teknik selftalk yang bertujuan untuk membangun keyakinan pada diri "YS" bahwa subjek mampu menuntaskan tugas-tugas hafalan juz'ama yang wajib dihafalkan setiap hari. Teknik ini juga bertujuan mengubah pikiran "YS" yang negatif menjadi sesuatu hal positif sehingga "YS" tidak selalu terfokus pada kekurangan yang dimiliki.

Penerapan intervensi selftalk ini merupakan hasil asesmen kognisi yang dilakukan peneliti untuk menentukan teknik yang tepat dan sesuai dengan kebutuhan subjek "YS". Sedangkan untuk meningkatkan perilaku menghafal juz'ama "YS", peneliti menerapkan terapi perilaku dengan teknik token ekonomi.

Teknik token ekonomi ini merupakan teknik yang digunakan untuk mengubah perilaku negatif seseorang menjadi perilaku positif melalui pemberian stimulus berupa token agar target perilaku yang ingin diubah tersebut dapat meningkat atau menurun sesuai dengan tujuan intervensi. Penerapan teknik token ekonomi ini bertujuan untuk meningkatkan perilaku menghafal juz'ama. Untuk melihat perubahan yang terjadi pada setiap pelaksanaan intervensi, peneliti mengamati tiga aspek yang dapat meningkatkan perilaku menghafal juz'ama subjek "YS" meliputi durasi menghafal, frekuensi menghafal, dan jumlah ayat yang dihafal. Di bawah ini dapat dilihat gambar 3 tentang kondisi akhir penelitian subjek "YS" sebagai berikut: 


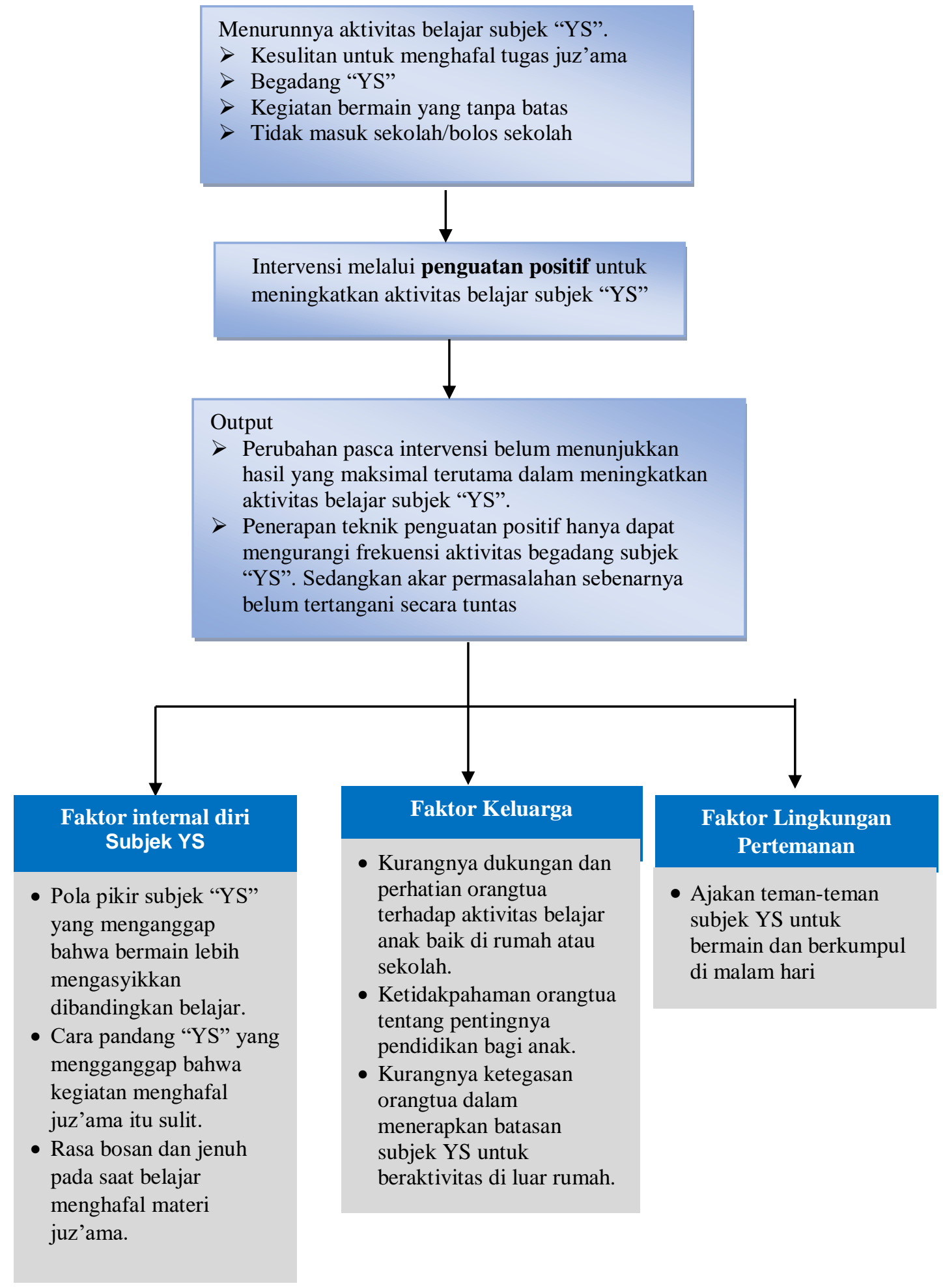

\section{Gambar 3 \\ Kondisi Akhir Penelitian Subjek "YS"}

Berdasarkan bagan di atas, bahwa kondisi akhir penelitian subjek "YS" ini lebih mengarah pada penurunan perilaku bergadangnya sedangkan untuk aktivitas belajar "YS" belum mendapatkan penanganan secara maksimal.
Pertimbangan tersebut menjadi poin penting bagi peneliti untuk lebih terfokus pada aspek kognitif dan perilaku subjek "YS" dalam meningkatkan aktivitas belajarnya terutama aktivitas menghafal. Pendekatan terapi perilaku 
kognitif yang diterapkan peneliti terhadap subjek "YS" membutuhkan lima sesi pertemuan.

Penerapan terapi perilaku kognitif ini digunakan untuk mengatasi masalah aktivitas belajar subjek "YS". Hal ini menjadi salah satu alasan peneliti melanjutkan intervensi mikro dalam kegiatan penelitian. Kondisi akhir penelitian subjek "YS" dijadikan sebagai baseline dalam kegiatan penelitian sehingga peneliti hanya perlu melakukan reasesmen untuk melihat kondisi subjek "YS" terkini. Pelaksanaan intervensi dengan menggunakan pendekatan tersebut memungkinkan timbulnya rasa bosan pada diri subjek atau mendapatkan pengaruh buruk dari lingkungan pertemanannya sehingga berdampak pada hasil yang belum maksimal. Namun dapat teratasi melalui penjelasan peneliti terkait prosedur pelaksanaan intervensi secara jelas dan detail kepada subjek dan orangtua. Hal ini menjadi dorongan bagi peneliti untuk melanjutkan penanganan masalah subjek YS hambatan dalam melakukan aktivitas belajar pascapenelitian di RW 09 Kelurahan Cipadung Kecamatan Cibiru Kota Bandung.

Anak merupakan amanah dan karunia dari Tuhan Yang Maha Esa, yang dalam dirinya melekat harkat dan martabat sebagai manusia seutuhnya. Selain itu juga, anak sebagai tunas bangsa yang merupakan generasi penerus bangsa, memiliki peran strategis, mempunyai ciri dan sifat khusus yang menjamin kelangsungan eksistensi bangsa dan negara pada masa depan.

Menurut UNICEF dalam Abu Huraerah (2006) mendefinisikan anak sebagai penduduk yang berusia antara 0 sampai 18 tahun. Hal di atas senada dengan definisi anak yang terdapat dalam Undang-Undang Nomor 35 Tahun 2014 perubahan dari Undang-Undang Nomor 23 Tahun 2002 tentang Perlindungan Anak mendefinisikan anak adalah seseorang yang belum berusia 18 tahun, termasuk anak yang masih dalam kandungan. Berdasarkan pengertian anak tersebut bahwa anak merupakan seseorang yang memiliki rentang usia 0 sampai dengan 18 tahun dan belum menikah, termasuk anak yang masih dalam kandungan. Anak juga memiliki pikiran, perasaan, dan sikap yang berbeda dengan orang dewasa dengan segala keterbatasan yang mereka miliki sehingga cenderung mereka masih membutuhkan kasih sayang, pemeliharaan, dan tempat untuk perkembangannya dari keluarga serta diharapkan keluarga juga dapat memberikan kesempatan kepada anak untuk belajar memahami tingkah laku untuk perkembangan anak tersebut.

Berdasarkan PERMENSOS Nomor 08 Tahun 2012 tentang Pedoman Pendataan dan Pengelolaan Data Penyandang Masalah Kesejahteraan Sosial dan Potensi Sumber Kesejahteraan Sosial menyebutkan pengertian anak terlantar adalah: Seorang anak berusia 6 (enam) tahun sampai dengan 18 (delapan belas) tahun, meliputi anak yang mengalami perlakuan salah dan ditelantarkan oleh orang tua/keluarga atau anak kehilangan hak asuh dari orangtua/keluarga dengan kriteria; 1). Berasal dari keluarga fakir miskin; 2). Anak yang dilalaikan oleh orangtuanya; dan 3). Anak yang tidak terpenuhi kebutuhan dasarnya.

Definisi anak terlantar dalam Undang-Undang Nomor 35 Tahun 2014 tentang Perlindungan Anak Pasal 1 menyatakan bahwa Anak terlantar adalah anak yang tidak terpenuhi kebutuhannya secara wajar, baik fisik, mental, spiritual, maupun sosial. Anak terlantar ini merupakan salah satu masalah sosial anak yang perlu mendapatkan penanganan. Batasan usia anak terlantar yaitu 6-18 tahun. Anak terlantar ini dapat diakibatkan oleh kondisi ekonomi keluarga yang tidak mampu, ketidakmampuan orangtua dalam menjalankan peranannya, kehilangan peranan dan pengasuhan orangtua sehingga membutuhkan adanya bantuan pelayanan dan penanganan secara komprehensif dari masyarakat dan pemerintah setempat.

Definisi belajar yang dikutip oleh Dalyono (2007:211) menyebutkan bahwa Witherington, dalam buku Educational Psychology 
mengemukakan: "Belajar adalah suatu perubahan di dalam kepribadian yang menyatakan diri sebagai suatu pola baru dari reaksi yang berupa kecakapan, sikap, kebiasaan, kepandaian, atau suatu pengertian.”

Hilgard dan Bower, dalam buku Theories of Learning (1975), mengemukakan: "Belajar berhubungan dengan perubahan tingkah laku seseorang terhadap sesuatu situasi tertentu yang disebabkan oleh pengalamannya yang berulang-ulang dalam situasi itu, di mana perubahan tingkah laku itu tidak dapat dijelaskan atau dasar kecenderungan respon pembawaan, kematangan, atau keadaankeadaan sesaat seseorang (misalnya kelelahan, pengaruh obat dan sebagainya)." Definisi tersebut dapat disimpulkan bahwa belajar merupakan suatu perubahan dalam tingkah laku, dimana perubahan itu dapat mengarah kepada tingkah laku yang lebih baik, tetapi juga ada kemungkinan mengarah kepada tingkah laku yang lebih buruk. Tingkah laku yang mengalami perubahan karena belajar menyangkut berbagai aspek kepribadian, baik fisik maupun psikis, seperti: perubahan dalam pengertian, pemecahan suatu masalah/berpikir, keterampilan, kecakapan, kebiasaan, ataupun sikap.

Belajar bertujuan untuk mengubah sikap, dari negatif menjadi positif, tidak hormat menjadi hormat, benci menjadi sayang, mengubah keterampilan, menambah pengetahuan dalam berbagai bidang ilmu, misalnya tidak bisa membaca, menulis, berhitung, berbahasa Inggris menjadi bisa semuanya. Berikut ini dikemukakan oleh Dalyono dalam Buku Psikologi Pendidikan (2007) beberapa contoh aktivitas belajar dalam beberapa situasi meliputi: a). Mendengarkan, b). Memandang, c). Meraba, membau, dan mencicipi/Mencecap, d). Menulis atau mencatat, e). Membaca, f). Membuat ikhtisar atau ringkasan, dan menggarisbawahi, g). Mengamati tabel-tabel, diagram-diagram dan bagan-bagan, h). Menyusun paper atau kertas kerja, i). Mengingat, j). Berpikir, dan k). Latihan atau Praktik.
Menurut Paul B.Diedric (Sardiman, 2011:101) jenis-jenis aktivitas dalam belajar digolongkan menjadi beberapa bagian sebagai berikut: a) Visual activities, yaitu segala kegiatan yang berhubungan dengan aktivitas siswa dalam melihat, mengamati, dan memperhatikan misalnya membaca, memperhatikan gambar demonstrasi, percobaan, pekerjaan orang lain; b) Oral Activities, yaitu aktivitas yang berhubungan dengan kemampuan siswa dalam mengucapkan, melafazkan, dan berfikir seperti menyatakan merumuskan, bertanya, memberi saran, berpendapat, diskusi, interupsi; c) Listening Activities, aktivitas yang berhubungan dengan kemampuan siswa dalam berkonsentrasi menyimak pelajaran, sebagai contoh mendengarkan: uraian, percakapan, diskusi, musik, pidato; d) Writing Activities, seperti misalnya menulis cerita, karangan, laporan, menyalin; e). Drawing Activities, menggambar, membuat grafik, peta, diagram. f) Motor Activities yaitu segala keterampilan jasmani siswa untuk mengekspresikan bakat yang dimilikinya yang termasuk di dalamnya antara lain: melakukan percobaan, membuat konstruksi, model, mereparasi, berkebun, beternak; h) Mental Activities, sebagai contoh misalnya: menanggapi, mengingat, memecahkan soal, menganalisis, mengambil keputusan; dan i) Emotional Activities, seperti misalnya, merasa bosan, gugup, melamun, berani, tenang.

Perkembangan teknik terapi Cognitive Behavior Therapy merupakan penggabungan dua teknik terapi yaitu teknik Behavior Therapy dikembangkan oleh Wolpe dan ahli lainnya pada tahun 1950an, dan Cognitive Therapy dikembagkan A.T Beck di awal 1960an. Berkembangnya Behavior Therapy merupakan kritik atau sanggahan yang menganggap bahwa teori psikoanalisa dari Sigmun Freud dianggap kurang empiris. Perkembangan teknik Behavior Therapy sangat pesat, tetapi terdapat juga kekurangan atau masalah yang muncul yang tidak tergali dalam teknik perubahan perilaku yaitu tidak adanya proses perubahan yang memperhatikan tentang perasaan, keyakinan, khayalan dan proses-proses kognitif lainnya. 
Pada tahun 1970an perkembangan Behavior Therapy sangat pesat sehingga berdampak pada ketidakpuasan dan sanggahan juga dari pendekatan Cognitive Therapy, sehingga pendekatan kognitif juga berkembang pesat dan memberikan sanggahan yang tidak dapat dilakukan dalam pendekatan perilaku. Kemajuan pendekatan perilaku dan kognitif berjalan seiring dan sejalan secara bersamaan dan memunculkan teknik baru yang merupakan perpaduan antara pendekatan perilaku dan pendekatan kognitif yaitu Cognitive Behavior Therapy (CBT).

Berdasarkan hal tersebut diatas maka dapat dilihat kerangka teori perkembangan pendekatan Cognitive Behavior Therapy pada gambar 4. Cognitive Behavior Therapy (CBT) merupakan pendekatan terapi yang didasarkan atas konseptualisasi atau pemahaman pada setiap responden, yaitu pada keyakinan khusus subjek dan pola perilaku subjek. Proses terapi dengan cara memahami subjek didasarkan pada restrukturisasi kognitif yang menyimpang, keyakinan subjek untuk membawa perubahan emosi dan strategi perilaku kearah yang lebih baik. Oleh sebab itu, CBT merupakan salah satu pendekatan yang lebih integratif dalam terapi (Alford dan Beck, 1997).

Beck (2011) mendefinisikan CBT sebagai pendekatan yang dirancang untuk menyelesaikan permasalahan subjek pada saat ini dengan cara melakukan restrukturisasi kognitif dan perilaku yang menyimpang. Pendekatan CBT didasarkan formulasi kognitif, keyakinan dan strategi perilaku yang mengganggu. Proses terapi didasarkan pada konseptualisasi atau pemahaman subjek atas keyakinan khusus dan pola perilaku subjek. Harapan dari CBT yaitu munculnya restrukturisasi kognitif yang menyimpang dan sistem kepercayaan untuk membawa perubahan emosi kearah lebih baik.

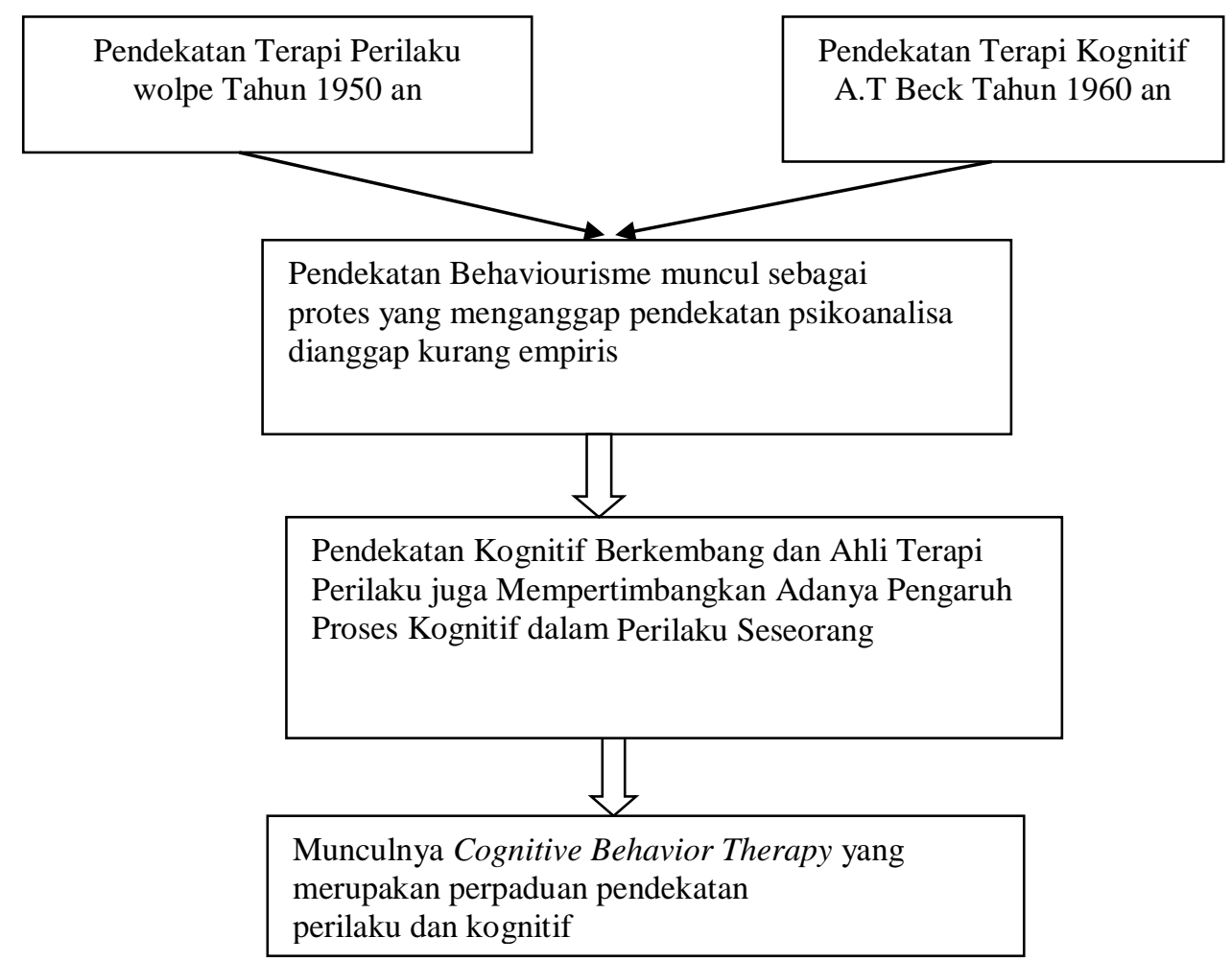

Gambar 4

Kerangka Teori

Perkembangan Pendekatan Cognitive Behavior Therapy 
Terapi Kognitif-Behavioral (TKB) atau Cognitive-Behavioral Therapy (CBT) merupakan salah satu bentuk konseling yang bertujuan membantu klien agar dapat menjadi lebih sehat, memperoleh pengalaman yang memuaskan, dan dapat memenuhi gaya hidup tertentu, dengan cara memodifikasi pola pikir dan perilaku tertentu. Pendekatan kognitif berusaha memfokuskan untuk menempatkan suatu pikiran, keyakinan, atau bentuk pembicaraan diri (self talk) terhadap orang lain. Terapi juga memfokuskan pada upaya membelajarkan klien agar dapat memiliki cara berpikir yang lebih positif dalam berbagai peristiwa kehidupan dan tidak hanya sekedar berupaya mengatasi penyakit atau gangguan yang sedang dialaminya. Dengan kata lain, konseling kognitif memfokuskan pada kegiatan mengelola dan memonitor pola fikir klien sehingga dapat mengurangi pikiran negatif dan mengubah isi pikiran agar dapat siperoleh emosi yang lebih positif. Sedangkan Konseling Behavioral memfokuskan pada kegiatan (tindakan) yang dilakukan klien, menentukan bentuk imbalan (rewards) yang dapat mendorong klien untuk melakukan tindakan tertentu, pemberian konsekuensi yang tidak menyenangkan, guna mencegah klien melakukan tindakan yang tidak dikehendaki.perasaan dan tingkah laku.

Tujuan dari terapi Cognitive Behavior (Oemarjoedi, 2003:9) yaitu mengajak subjek untuk menentang pikiran dan emosi yang salah dengan menampilkan bukti-bukti yang betentangan dengan keyakinan mereka tentang masalah yang dihadapi. Terapis diharapkan mampu menolong subjek untuk mencari keyakinan yang sifatnya dogmatis dalam subjek dan secara kuat menguranginya.

Menurut Sheafor dan Horeshji (2003) menyebutkan bahwa tujuan penerapan terapi perilaku kognitif ini yaitu untuk memperbaiki keberfungsian sosial dengan membantu klien untuk mempelajari cara yang lebih realistik dan positif dalam mempersepsikan, memikirkan tentang arti hidup. Pendekatan terapi ini memerlukan klien yang memiliki persyaratan kapasitas intelektual dan bersedia untuk meluangkan waktu yang dibutuhkan untuk memonitor dan menganalisa cara dia dalam berpikir serta mempraktikkan teknik yang telah dirancang untuk mengubah kebiasaan berfikir yang telah tertanam sejak lama.

Langkah-langkah penerapan terapi perilaku kognitif (cognitive behavior therapy) yang dinyatakan oleh Ronen sebagai berikut; a). Inventory of problem areas. Bertujuan untuk mengumpulkan informasi yang diperlukan sehubungan dengan permasalahan yang dihadapi; b). Problem selection and contract, yaitu mencapai kesepakatan tentang masalah yang ingin diubah dan membuat kontrak kerjasama; c). Commitment to cooperate. Tujuannya adalah untuk memfasilitasi agar klien dapat termotivasi untuk mematuhi kesepakatan yang harus dilakukan selama proses intervensi; d). Specification of target behaviors. Merinci setiap perilaku yang akan diubah atau dimodifikasi; f). Baseline assessment of target behavior. Pengumpulan data tentang frekuensi dan durasi masalah yang muncul, sebagai dasar dalam mengevaluasi perubahan; g). Identification of problem-controlling condition. Mengidentifikasi kondisi yang dapat mengendalikan masalah; h). Assessment of environmental resources. Mencari sistem sumber di dalam lingkungan klien; i). Specification of behavioral objectives. Menentukan perilaku yang ingin dicapai dalam rencana modifikasi perilaku; k). Formulation of a modification plan. Membuat rencana teknik yang sesuai untuk perubahan perilaku; 1). Implementation of modification plan. Memodifikasi perilaku dan berfokus pada upaya perubahan; m). Monitoring of outcomes. Mengumpulkan informasi mengenai efektifitas intervensi; dan $\mathrm{n}$ ). Maintenance of change. Memelihara kestabilan hasil agar perilaku lama tidak kambuh.

Teknik yang digunakan dalam penelitian ini menggunakan perpaduan antara Cognitive Therapy dan Behavior Therapy. Adapun teknik yang digunakan oleh peneliti dalam 
penelitian ini yaitu teknik selftalk dan token ekonomi.

Selftalk: Istilah self-talk mengacu pada pesan yang kita berikan sendiri. Apa yang kita katakan pada diri kita sendiri menggambarkan interpretasi unik kita tentang yang telah kita alami. Pekerja sosial mengambil situasi teoritis terapi kognisi menekankan bahwa selftalk menggugah reaksi emosional yang pada gilirannya memunculkan perilaku

Pekerja sosial dapat menggunakan 5 langkah pendekatan untuk menolong klien memperbaharui kerusakan dalam self-talk. Menurut Sheafor dan Horesji (2003:410) menyatakan bahwa langkah-langkah dalam menerapkan selftalk kepada klien sebagai berikut: a) Tentukan apa yang Anda rasakan dan pikirkan saat ini; b) Berhubunganlah dengan self-talk. Perhatikan pemikiran yang ekstrim seperti yang disarankan dengan menggunakan kata seperti tidak pernah, selalu, setiap orang, dengan sempurna; c) Amati realitas tujuan dari situasi Anda. Satu kali fakta telah ditentukan, relaks dan menarik nafas dalam-dalam dan ulangi lagi dengan suara yang keras selama 3 kali; d) Perhatikan ketika Anda tetap pada kenyataan dan menghindari penggunaan kata-kata yang tidak tepat, Anda mulai merasakan berbeda dan segala sesuatunya tidak sejelek sebelumnya; dan e) Tetap pegang kenyataan situasi Anda dengan jelas, perhatikan apa yang dapat Anda lakukan tentang ini.

Token Ekonomi: Menurut Nono Sutisna dkk (2012), menyebutkan bahwa "Token adalah penguat yang berupa barang-barang/ bendabenda yang melambangkan berbagai satuan nilai yang diinginkan bagi individu yang dapat ditukarkan dengan sesuatu yang diinginkan orang tersebut, contoh: point, voucher, kupon (token ekonomi). Bisa juga berupa token sosial apabila penguatan yang diberikan berupa pujian atau penghargaan secara sosial"

Adi Fahrudin (2012) mengungkapkan bahwa seorang individu akan menerima token dengan segera setelah menampilkan perilaku yang disenangi, sebaliknya akan mendapat pengurangan token jika menampilkan perilaku yang tidak disukai. Token-token ini dikumpulkan dan kemudian dalam jangka waktu tertentu dapat ditukarkan dengan hadiah atau sesuatu yang mempunyai makna. Secara singkatnya Token ekonomi merupakan sebuah sistem reinforcement untuk perilaku yang dikelola dan diubah, seseorang mesti dihadiahi/ diberikan penguatan untuk meningkatkan atau mengurangi perilaku yang diinginkan.

Menurut Nono Sutisna dkk (2012) ada beberapa tujuan dalam penerapan teknik token ini, antara lain: a). Mengembangkan perilaku positif atau menghambat munculnya perilaku yang tidak diinginkan, dan b). Memberikan keterampilan-keterampilan positif yang bisa dijadikan fungsi sosialnya.Tujuan utama dari "Token Ekonomi" dikemukakan oleh Miltenberger (2001) adalah meningkatkan perilaku yang disukain (baik) dan mengurangkan perilaku tidak disukai. Adi Fahrudin (2012) mengungkapkan bahwa umumnya token ekonomi digunakan dalam pengubahan perilaku di setting institusional (termasuk rumah sakit jiwa, lembaga koreksional atau pusat rehabilitasi) untuk mengatur perilaku individu yang agresif atau tidak dapat diprediksi. Bagaimanapun, tujuan token ekonomi yang lebih besar adalah mengajarkan tingkah laku yang tepat dan keterampilan sosial yang dapat dipergunakan dalam suatu lingkungan alamiah.

Pelaksanaan teknik token ekonomi dalam penelitian ini dilaksanakan melalui beberapa tahapan dengan merujuk pada pendapat Nono Sutisna (2012) mengenai prosedur pelaksanaan teknik token ekonomi, sebagai berikut:

Melakukan asesmen perilaku: Asesmen perilaku dalam penerapan teknik token ekonomi ditujukan untuk menentukan target sasaran perilaku yang akan diberikan treatment. Adapun sasaran perilku pada penelitian ini yaitu: perilaku menghafal juz'ama, aspek-aspek yang diteliti antara lain 
durasi menghafal, frekuensi menghafal dalam sehari, dan jumlah ayat yang dihafal subjek "YS". Penentuan sasaran perilaku tersebut ditentukan berdasarkan hasil asesmen yang dilakukan peneliti pascapenelitian. Hasil asesmen menunjukkan bahwa subjek "YS" mengalami kesulitan dalam menghafal juz'ama, sehingga seringkali untuk menghindari tugas hafalan di sekolah lebih memilih untuk tidak masuk sekolah/bolos pada jam pelajaran tersebut. Penanganan masalah subjek "YS" memerlukan intervensi lanjut agar pencapaian perilaku yang diinginkan mengalami peningkatan dibandingkan saat penelitian awal berlangsung.

Menemukan token efektif yang dapat memberikan kepuasan untuk mendukung munculnya perilaku positif. Penentuan token pada penelitian ini ditentukan oleh peneliti bersama dengan subjek "YS", token yang digunakan berbentuk bintang berwarna yang didesain langsung oleh peneliti.

Menyepakati tingkah laku baru dan meminimalisir perilaku negatif yang ingin dihilangkan. Peneliti membantu subjek "YS" untuk mengatasi hambatan belajar yang sedang dialaminya. Kemudian, peneliti juga memberikan motivasi agar "YS" bersedia melaksanakan kegiatan sesuai dengan kesepakatan untuk meningkatkan perilaku menghafal juz'ama.

Mengembangkan alternative perilaku positif dan mendiskusikan dengan klien. Peneliti bersama subjek "YS" menentukan bentuk tingkah laku baru yang perlu ditingkatkan oleh subjek "YS". Hal ini ditunjukan agar subjek mampu memperoleh pengalihan perilaku yang tidak sesuai dengan meningkatkan perilaku positif. Bentuk perilaku yang ditingkatkan tersebut yaitu meningkatkan perilaku menghafal juz'ama dilihat dari aspek durasi menghafal, frekuensi menghafal, dan jumlah ayat yang dihafal.

Menciptakan suasana yang mendukung proses diskusi (rileks, terbuka, memperlihatkan kedekatan, ventilasi).
Menyepakati token dan aturan pemberian token untuk menghasilkan perilaku positif. Peneliti bersama subjek "YS" menentukan bentuk hadiah yang dapat ditukarkan oleh subjek "YS". Token bintang ini ditukarkan berdasarkan jumlah token yang terkumpul selama sesi pelaksanaan intervensi yang berlangsung selama lima sesi. Penukaran token dilakukan pasca pelaksanaan intervensi. Adapun bentuk hadiah yang disepakati bersama subjek "YS" antara lain uang Rp. 10.000 , pulsa Rp. 20.000, alat tulis sekolah, dan kaos.

\section{Tujuan}

Penelitian ini bertujuan untuk mengetahui: 1) Kondisi aktivitas belajar (aktivitas menghafal) subjek penelitian, 2) Penerapan terapi perilaku kognitif (Cognitive Behaviour Therapy) dalam meningkatkan aktivitas belajar (menghafal juz'ama) "YS".

\section{Metode}

Pendekatan penelitian yang digunakan dalam menerapkan terapi perilaku kognitif untuk meningkatkan aktivitas belajar "YS" yaitu kuantitatif. Menurut Suyigono (2012:7), penelitian kuantitatif merupakan penelitian yang berlandaskan pada filsafat positivism, digunakan untuk meneliti pada populasi atau sampel tertentu.Metode yang digunakan dalam pendekatan kuantitatif yaitu metode desain subjek tunggal/single subject design, dimana $\mathrm{N}=1$. Unit analisisnya adalah tunggal yaitu satu individu (YS berusia 13 tahun). Penelitian dengan desain subjek tunggal merupakan salah satu metode evaluasi yang digunakan dalam praktik pekerjaan sosial untuk mengevaluasi suatu teknik atau program.

Penelitian subjek tunggal perlu menentukan target perilaku yang ingin dicapai, perlu adanya monitoring yang intens dan berkelanjutan selama pelaksanaan penelitian, penentuan intervensi yang tepat untuk mengurangi atau meningkatkan target perilaku yang diinginkan, serta pengukuran terhadap target perilaku secara berulang-ulang sebelum dan sesudah 
intervensi dengan periode waktu tertentu misalnya per jam, per hari, per minggu, atau per bulan. Sunanto (2006:6) menyatakan bahwa penelitian subjek tunggal sangat efektif dalam kegiatan modifikasi peilaku. Modifikasi perilaku adalah kegiatan yang sebagian besar diaplikasikan pada perilaku manusia seperti dalam proses pengajaran, pendidikan, dan kesejahteraan sosial. Perilaku yang dimaksud dalam penelitian ini tidak hanya terfokus pada ranah psikomotor, tetapi juga berkaitan dengan pikiran (kognitif), perasaan (afektif), dan perbuatan (psikomotor) yang dapat diamati, terukur, dan dicatat (Sunanto, 2006:6).

Model rancangan penelitian yang digunakan yaitu model A1-B-A2. A menunjukkan kondisi baseline yang merupakan kondisi dimana pengukuran perilaku sasaran dilakukan pada keadaan natural sebelum diberikan intervensi apapun. Sedangkan B menunjukkan kondisi intervensi merupakan kondisi ketika intervensi telah diberikan dan perilaku sasaran diukur di bawah kondisi tersebut. Fase A2 menunjukkan fase hasil dimana pengukuran dan pengamaatan dilakukan oleh peneliti pasca diberikannya intervensi. Dalam penelitian desain subjek tunggal selalu dilakukan perbandingan dengan subjek yang sama dalam kondisi yang berbeda. Hal ini berkaitan dengan analisis data yang bertujuan untuk melihat perbandingan kondisi subjek pada setiap fase dan antar kedua fase.

Prosedur dasar yang dilakukan pada model A1B-A2 dilakukan pengukuran target perilaku secara kontinyu pada kondisi baseline (A1) dengan periode waktu selama lima sesi pertemuan, kemudian dilanjutkan dengan pengukuran pada kondisi intervensi (B) yang duilakukan selama lima (5) sesi, terakhir dilakukan pengukuran baseline kembali pasca intervensi (A2) selama lima (5) sesi sehingga total keseluruhannya menjadi 15 sesi. Istilah sesi ini digunakan oleh peneliti dikarenakan jadwal kegiatan penelitian tidak dilakukan setiap hari secara berurutan, namun berdasarkan kesepakatan dan kesediaan subjek "YS" seperti seminggu tiga kali. Pengukuran pada kondisi baseline 2 (A2) ini dimaksudkan sebagai kontrol untuk kondisi intervensi. (lihat Gambar 5)

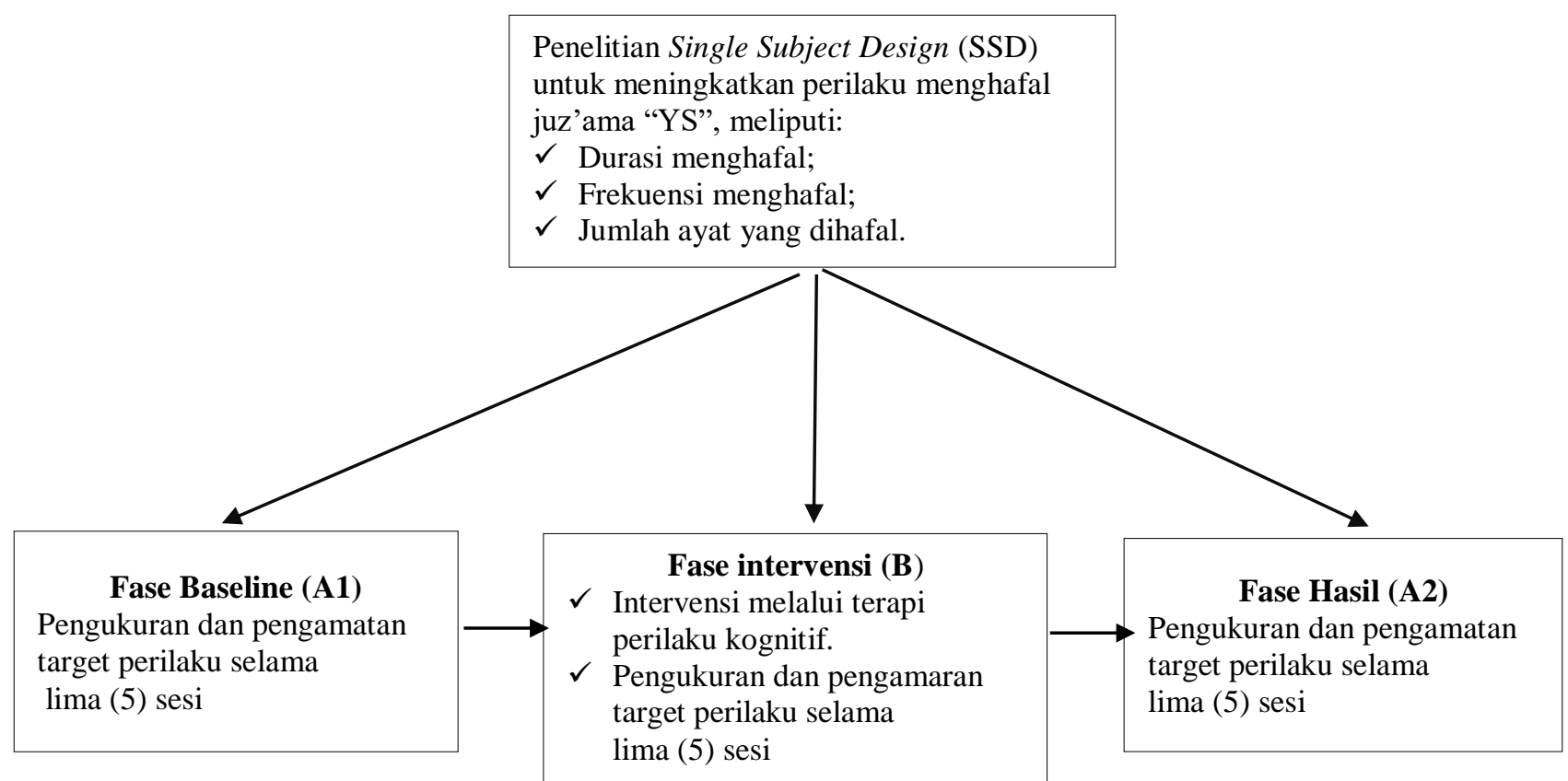

Gambar 5

Prosedur Penelitian Model ABA 
Subjek dalam penelitian ini adalah YS, seorang anak laki-laki yang berusia 13 tahun. Saat ini, "YS" duduk di bangku sekolah tingkat 5 . Sekolah "YS" merupakan sekolah berbasis islami sehingga ada mata pelajaran yang wajib dihafal setiap hari yaitu materi juz'ama. "YS" mengalami kesulitan dalam menghafal materi tersebut, hal ini dikarenakan cara berpikir "YS" yang salah sehingga menampilkan perilaku yang negatif. Target perilaku yang ingin diteliti yaitu perilaku menghafal juz'ama. perilaku menghafal juz'ama ini dilihat dari tiga aspek antara lain durasi menghafal, frekuensi menghafal, dan jumlah ayat yang dihafal.

Instrumen penelitian yang digunakan oleh peneliti yaitu menggunakan lembar pencacatan observasi yang telah disahkan oleh dosen pembimbing. Lembar pencatatan observasi ini bertujuan untuk mengamati dan mengukur target perilaku menghafal juz'ama yang dilakukan oleh subjek "YS" pada fase baseline (A1), fase intervensi (B), dan fase hasil (A2). Instrumen penelitian tersebut berisikan gambaran tentang berapa banyak jumlah ayat yang dihafal, durasi menghafal, dan frekuensi menghafal dalam sehari. Selain itu juga, melalui instrumen lembar pencacatan ini dapat diketahui identitas subjek, waktu dan tempat pengamatan, orang yang bertugas sebagai pengamat, dan lamanya pengamatan sehingga dapat terlihat perubahan data yang diperoleh baik pada setiap kondisi atau antar kondisi.

Instrumen yang valid dan reliabel merupakan syarat yang mutlak untuk mendapatkan hasil penelitian yang valid dan reliabel. Sugiyono (2012:121) menyatakan bahwa instrumen yang valid berarti instrumen yang dapat digunakan untuk mengukur apa yang seharusnya diukur. Sedangkan instrumen yang reliabel merupakan instrumen yang apabila digunakan untuk mengukur objek yang sama, akan menghasilkan data yang sama.

Validitas yang digunakan dalam penelitian ini yaitu validitas isi (content validity) atau validitas tampak. Untuk mencapai validitas isi/validitas tampak, maka instrumen alat ukur yang digunakan untuk mengamati perilaku menghafal juz'ama subjek "YS" berisikan tentang konsep-konsep yang berkaitan dengan perilaku tersebut. Kesesuaian instrumen antara konsep perilaku yang diukur dengan informasi yang dibutuhkan dalam melakukan pengukuran, menunjukkan bahwa instrumen tersebut memiliki validitas isi. Peneliti menggunakan uji validitas pencatatan kejadian yaitu dengan cara memberikan tanda (dengan memberi tally) pada kertas yang telah di sediakan setiap kejadian atau perilaku terjadi samapai dengan periode waktu observasi yang telah ditentukan (Sunanto:19).

Uji reliabilitas instrumen yang digunakan pada penelitian ini menggunakan reliabilitas antarpengukur (inter-rater reliability). Uji reliabilitas ini yaitu untuk melihat tingkat kesepakatan (agreement) antar ahli atau rater dalam menilai setiap indikator atau aspek pada instrumen. kesepakatan antar rater dapat dicapai ketika masing-masing rater memiliki persepsi yang sama terhadap apa yang dinilai dan diobservasi. Berdasarkan pendapat tersebut, reliabilitas antar-pengukur (inter-rater reliability) adalah pengukuran yang melibatkan pengukur (rater) untuk menilai suatu instrument hingga terjadi kesepakatan.

Menurut Tawney dan Gast dalam Sunanto (2006:17) menyatakan bahwa terdapat tiga macam prosedur pencatatan data yang digunakan dalam penelitian modifikasi perilaku, yaitu pencacatan data secara otomatis, pencacatan data dengan produk permanen, dan pencatatan data dengan observasi langsung. Sistem pencacatan data atau pengumpulan data yang digunakan oleh peneliti antara lain: a) Pencatatan Produk Permanen, b) observasi, c). wawancara, dan d). studi dokumentasi.

Pencatatan produk permanen ini merupakan suatu hasil dari tindakan atau perilaku yang dikerjakan oleh subjek. Pencacatan dengan produk permanen ini dilakukan terhadap variabel atau perilaku sasaran yang ditampilkan oleh subjek dengan data secara langsung berada pada dokumen tertentu. Dalam penelitian ini, target perilaku yang diubah yaitu perilaku menghafal juz'ama. Peneliti 
mengamati kemampuan menghafal juz'ama "YS" berdasarkan lamanya waktu menghafal, frekuensi menghafal, dan jumlah ayat yang dihafal. Untuk melihat perubahan perilaku pada setiap fase, peneliti hanya mendengarkan bacaan juz'ama yang dilafalkan oleh "YS" dengan melihat panduan dalam buku juz'ama. Oleh karena itu, pengumpulan data dengan produk permanen hanya terfokus pada dokumen yang telah tersedia yaitu buku panduan juz'ama.

Dalam proses observasi, peneliti mengamati perilaku menghafal juz'ama subjek "YS". Pengamatan ini dilakukan dengan memperhatikan kemampuan menghafal "YS" dilihat dari lamanya waktu menghafal/durasi, jumlah ayat yang dihafal, dan frekuensi menghafal dalam sehari. Pengamatan ini berlangsung selama 15 sesi pertemuan yang dilakukan pada saat sebelum, setelah, dan saat intervensi.

Wawancara langsung kepada subjek penelitian menggunakan jenis pertanyaan yang semi terstruktur dan berpedoman pada seperangkat pertanyaan yang telah disiapkan sesuai dengan rumusan masalah. Informasi yang ingin digali melalui kegiatan wawancara meliputi mata pelajaran yang disajikan di sekolah "YS" termasuk mata pelajaran yang menyajikan tugas-tugas hafalan, aktivitas belajar secara umum baik di sekolah maupun di rumah seperti menghafal materi juz'ama.

Menurut Sunanto (2006:65) menyebutkan bahwa teknik analisis data yang digunakan dalam penelitian desain subjek tunggal yaitu analisis inspeksi visual dengan menggunakan statistik deskriptif yang sederhana. Ada tiga hal yang perlu diperhatikan dalam menganalisis data antara lain pembuatan grafik untuk melihat hasil pengukuran dan pengamatan target perilaku subjek, penggunaan statistik deskriptif, dan analisis inspeksi visual. Tujuan utama analisis data dalam bidang modifikasi perilaku yaitu untuk mengetahui efek atau pengaruh intervensi terhadap perilaku sasaran yang ingin diubah (Sunanto,2006:65). Komponen analisis data yang terdapat dalam analisis inspeksi visual antara lain: a). Analisis dalam kondisi, dan b). Analisis antarkondisi.

Pada tahap analisis dalam kondisi, peneliti melakukan analisis terhadap perubahan data yang terjadi pada suatu kondisi misalnya kondisi baseline atau kondisi intervensi. Komponen yang dianalisis dalam kondisi ini meliputi a) Panjang kondisi, b) Kecenderungan arah, c). Tingkat stabilitas, d) Tingkat perubahan, e) Jejak data, dan f) Rentang. Sedangkan dalam analisis antarkondisi, Peneliti melakukan analisis perbandingan antara kondisi baseline dengan kondisi intervensi. Kegiatan analisis ini dapat dilakukan apabila kondisi sudah dapat dikatakan stabil dan tidak terjadi overlap. Komponen utama yang perlu dianalisis meliputi: a) Jumlah variabel yang diubah, b) Perubahan kecenderungan arah dan efeknya, c) Perubahan stabilitas, d) Perubahan level, dan e) Data tumpang tindih (overlap).

\section{Hasil dan Pembahasan}

Subjek dalam penelitian ini hanya satu (1) anak yang masuk dalam kategori anak terlantar yaitu "YS" berusia 13 tahun. Keterlantaran yang terjadi pada subjek ini diakibatkan oleh cara pengasuhan orangtua yang kurang tepat, sehingga subjek mengalami perubahan perilaku yang mengarah ke hal-hal yang negatif seperti merokok, minum-minuman keras, dan bolos sekolah. Perilaku maladaptif tersebut menyebabkan menurunnya motivasi belajar subjek sehingga aktivitas belajarnya juga terganggu baik di rumah maupun di sekolah. Salah satunya yaitu aktivitas menghafal materi juz'ama di sekolah, subjek menganggap bahwa aktivitas ini sangat membosankan, sulit, dan menyita waktu bermainnya.

Subjek dalam penelitian ini merupakan salah satu sampel dari lima anak terlantar yang menjadi fokus penelitian. Pertimbangan dipilihnya subjek ini dikarenakan masih perlu mendapatkan penanganan lebih lanjut pasca diberikannya intervensi penguatan positif dibandingkan dengan yang lain. 
Hasil penelitian yang telah dilakukan peneliti dalam menerapkan terapi perilaku kognitif ini disajikan dalam bentuk analisis data. Analisis data dalam penelitian ini bertujuan untuk mengetahui efek atau pengaruh intervensi terhadap perilaku sasaran yang ingin diubah. Selanjutnya, analisis data yang digunakan dalam penelitian dengan desain subjek tunggal yaitu analisis inspeksi visual. Analisis ini dilakukan melalui pengamatan secara langsung terhadap data yang telah ditampilkan dalam grafik. Ada dua cara untuk melakukan analisis inspeksi visual. yaitu analisis dalam kondisi dan analisis antar kondisi. Komponen yang terdapat dalam analisis dalam kondisi meliputi panjang kondisi, kecenderungan arah, jejak data, level stabilitas dan rentang, perubahan level. Sedangkan komponen yang ada dalam analisis antar kondisi meliputi jumlah variabel yang diubah, perubahan kecenderungan arah dan efeknya, perubahan stabilitas, perubahan level, dan data overlap.

Data hasil penelitian desian subjek tunggal ini disajikan dalam bentuk grafik. Grafik ini bertujuan untuk melihat data hasil pengukuran dan pengamatan perilaku sasaran "YS" dalam suatu kondisi yang berbeda yakni fase baseline, intervensi, dan hasil. Peneliti menyajikan grafik yang menunjukkan hasil pengukuran dan pengamatan terhadap perilaku menghafal juz'ama "YS" dengan beberapa indikator atau aspek perilaku antara lain lamanya menghafal, banyaknya jumlah ayat yang mampu dihafalkan, dan banyaknya perilaku menghafal yang dilakukan dalam sehari. Adapun di bawah ini data hasil pengukuran dan pengamatan terhadap perilaku menghafal juz'ama "YS" dengan model ABA selama 15 sesi. (lihat Tabel 1).

Berdasarkan tabel I bawah ini, dapat disimpulkan bahwa rata-rata kemampuan menghafal juz'ama "YS" dilihat dari aspek lamanya menghafal yaitu selama 30-34 menit dengan jumlah ayat yang dihafalkan sebanyak 4-5 ayat. Begitu juga dengan frekuensi menghafal yang merupakan banyaknya perilaku menghafal yang dilakukan subjek YS dalam sehari mencapai 1 (satu) kali baik itu di pagi hari, siang hari, dan sore hari. Berikut di bawah ini data hasil pengukuran perilaku menghafal juz'ama "YS" yang dituangkan dalam grafik pada gambar 6. Gambar 6 menunjukkan data point yang diperoleh peneliti pada saat melakukan pengukuran dan pengamatan. Tujuannya yaitu untuk melihat perkembangan perilaku menghafal juz'ama subjek YS pada tiga fase yang berbeda. Data hasil pengukuran tersebut kemudian diolah dan dianalisa menggunakan analisis dalam kondisi dan antarkondisi. Gambar 6 tersebut dapat menggambarkan bahwa lamanya sesi yang digunakan peneliti untuk masing-masing fase yaitu sebanyak 5 (lima) sesi, sehingga jumlah keseluruhannya mencapai 15 sesi.

Tabel 1

Data Hasil Pengukuran dan Pengamatan

Perilaku Menghafal Juz'ama Subjek "YS"

\begin{tabular}{|c|c|c|c|c|c|c|c|c|c|c|c|c|c|c|c|c|}
\hline \multirow[t]{3}{*}{ No. } & \multirow{3}{*}{$\begin{array}{c}\text { Target Perilaku } \\
\text { Menghafal Juz'ama }\end{array}$} & \multicolumn{5}{|c|}{ Fase Baseline (A1) } & \multicolumn{5}{|c|}{ Fase Intervensi (B) } & \multicolumn{5}{|c|}{ Fase Hasil (A2) } \\
\hline & & \multicolumn{15}{|c|}{ Sesi Ke- } \\
\hline & & 1 & 2 & 3 & 4 & 5 & 6 & 7 & 8 & 9 & 10 & 11 & 12 & 13 & 14 & 15 \\
\hline 1 & Durasi Menghafal (menit) & 30 & 30 & 30 & 30 & 30 & 60 & 60 & 60 & 60 & 60 & 30 & 30 & 30 & 30 & 30 \\
\hline 2 & $\begin{array}{l}\text { Frekuensi Menghafal } \\
\text { dalam Sehari }\end{array}$ & 1 & 1 & 1 & 1 & 1 & 1 & 1 & 2 & 2 & 2 & 1 & 1 & 1 & 1 & 1 \\
\hline 3 & Jumlah Ayat yang Dihafal & 3 & 3 & 2 & 3 & 3 & 4 & 6 & 6 & 6 & 7 & 3 & 3 & 4 & 5 & 5 \\
\hline
\end{tabular}

Sumber: Hasil Penelitian Pelayanan Anak di Cipadung Tahun 2017 


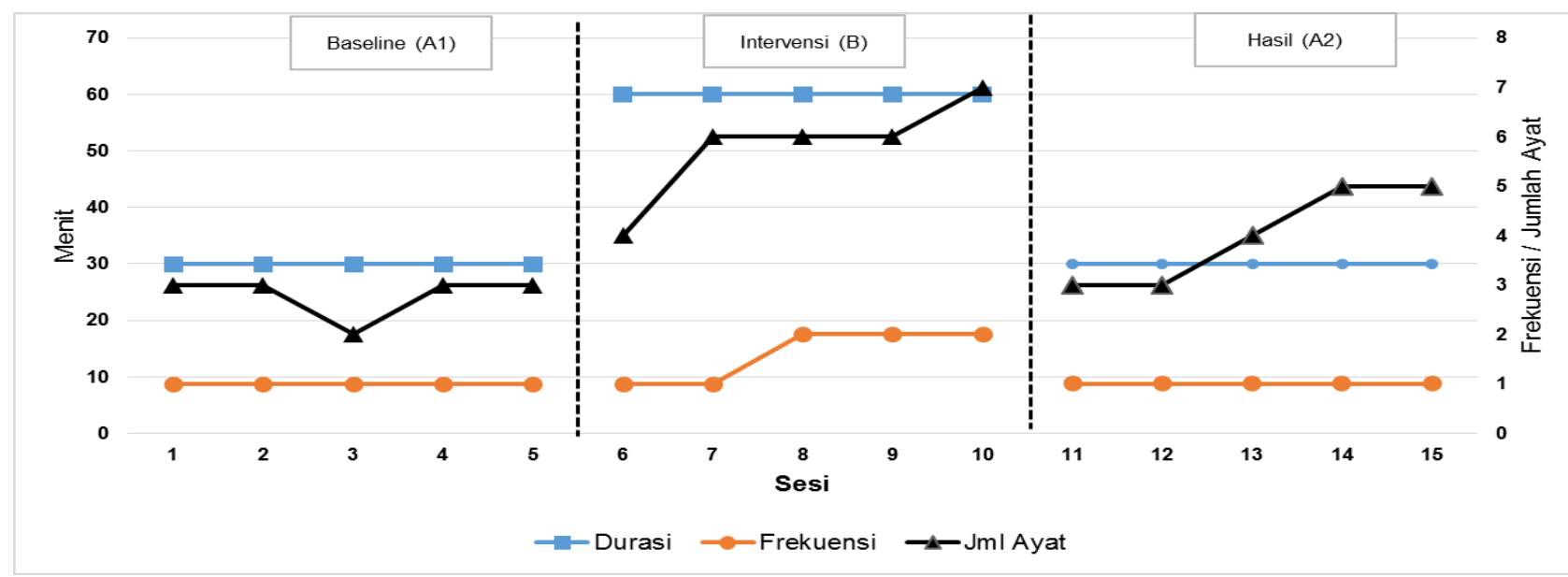

Gambar 6

Hasil Pengamatan dan Pengukuran

Perilaku Menghafal Juz'ama Subjek YS

Pemilihan banyaknya sesi ini tergantung pada kebutuhan penelitian dan tujuan intervensi yang akan dilakukan peneliti terhadap subjek YS. Di bawah ini dapat dilihat rangkuman hasil analisis data dalam kondisi pada tabel 2. Tabel menjelaskan bahwa analisis dalam kondisi ini merupakan salah satu cara untuk menganalisis perubahan data yang terjadi pada suatu kondisi seperti menganalisis data antara kondisi baseline dan kondisi intervensi. Berdasarkan rangkuman tabel analisis tersebut, komponen yang menjadi bagian penting untuk dianalisis antara lain berhubungan dengan kecenderungan arah, kecenderungan stabilitas, kecenderungan jejak data, level stabilitas dan rentang, dan perubahan level.

Pertama, data hasil kecenderungan arah "YS" untuk melihat perilaku menghafal juz'ama menunjukkan trend menaik dan mendatar. Kecenderungan arah yang menaik artinya bahwa terjadinya peningkatan dari kondisi sebelumnya baik itu terjadi fase intervensi maupun fase hasil. Data penelitian yang memiliki hasil trend menaik yaitu terjadi pada aspek jumlah perilaku menghafal yang dilakukan dalam sehari/frekuensi dan aspek jumlah ayat yang dihafal. Kecenderungan arah yang menaik pada aspek frekuensi terjadi pada fase intervensi dari satu kali menghafal menjadi dua kali dalam sehari (pagi hari dan siang atau sore hari). Selain itu, kecenderungan arah yang menaik juga terjadi pada aspek jumlah ayat yang dihafal. Kemampuan "YS" dalam menghafal ayat-ayat dalam materi juz'ama mengalami peningkatan hingga 7 ayat. Begitu juga dengan kemampuan "YS" dalam melafalkan bacaan surat juz'ama. Subjek YS menghafalkan bacaan surat Al-Infhitar dan AlMuthafifin dengan fasih, biasanya "YS" melafalkan bacaan dengan terbata-terbata dan perlu bimbingan untuk mengingatkan kembali setiap ayatnya.

Peningkatan ini terjadi dikarenakan "YS" termotivasi untuk menghafal juz'ama pasca diberinya stimulus berupa beberapa token yang memang diinginkan oleh "YS". Meningkatnya perilaku tersebut dikarenakan intervensi yang diberikan memberikan pengaruh kuat terhadap perubahan perilaku pada kondisi intervensi dibandingkan kondisi sebelumnya. Suatu kondisi dengan data yang menunjukkan trend "menaik" merupakan salah satu keefektifan penerapan teknik token ekonomi dalam mengubah perilaku "YS". Perubahan perilaku yang terjadi pada "YS", semata-mata bukan hanya karena intervensi yang telah dilakukan peneliti tetapi faktor intern dan ekstern "YS" menjadi faktor utama terjadinya peningkatkan perilaku menghafal juz'ama. Kondisi psikologis "YS" yang lebih antusias menjadikan ia bersemangat dan senang untuk belajar menghafal materi juz'ama dengan baik. Selanjutnya, cara berpikir "YS" yang lebih memahami pentingnya menghafal menjadi salah satu faktor yang dapat meningkatkan perilaku menghafal juz'ama. 
Tabel 2

Rangkuman Hasil Analisis dalam Kondisi

Subjek "YS"

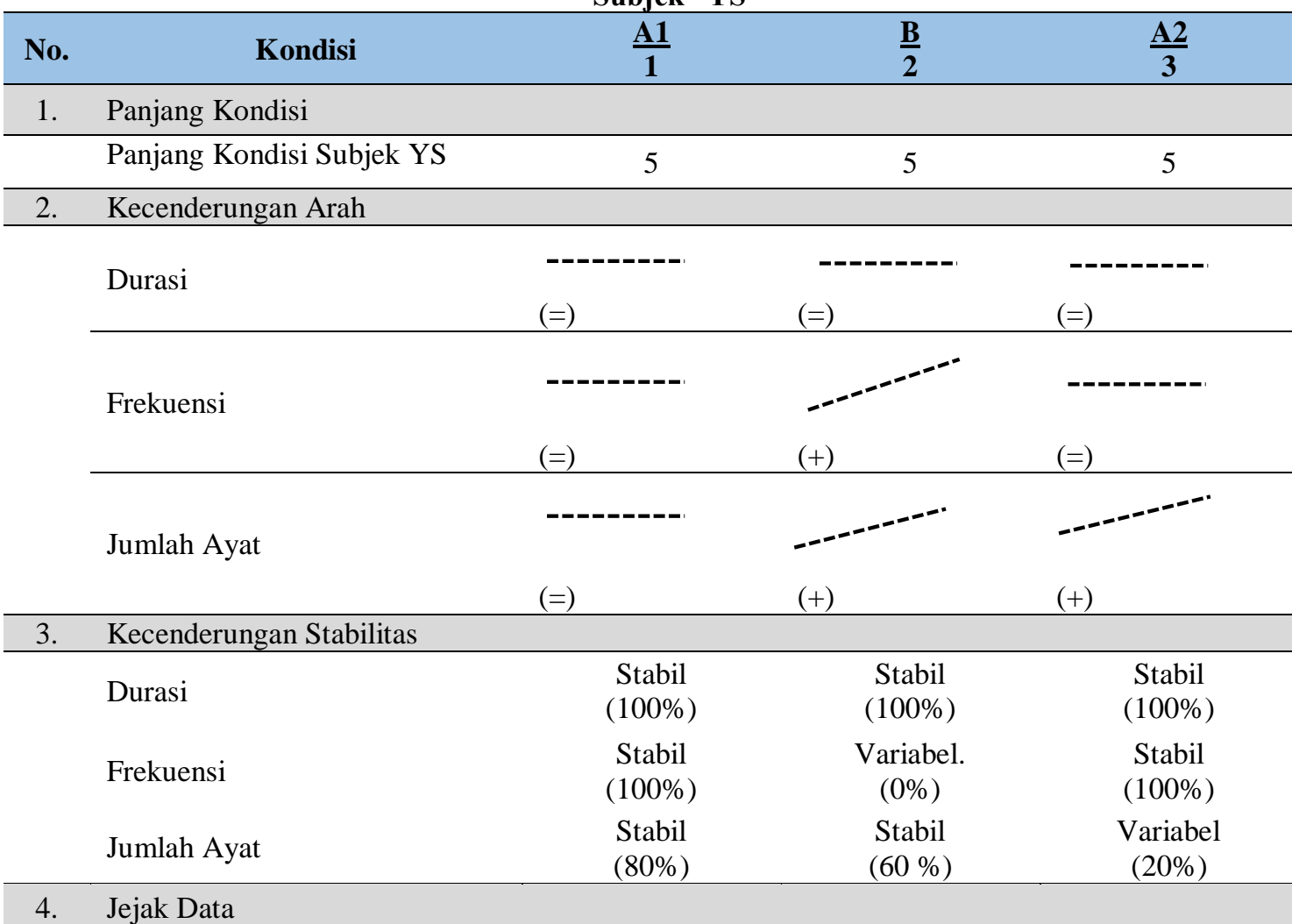

4. Jejak Data

Durasi

$(=)$

$(=)$

$(=)$

Frekuensi

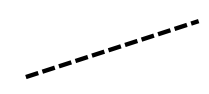

$(=)$

$(+)$

$(=)$

Jumlah Ayat

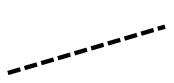

(+)

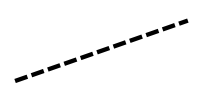

$(+)$

\section{Level Stabilitas dan Rentang}

$(=)$

$\frac{\text { Stabi }}{60}$

$\underline{\text { Stabil }}$

60

30

Variabel

1-2

$\underline{\text { Stabil }}$

Frekuensi

$\underline{\text { Stabil }}$

$\underline{\text { Stabil }}$

Jumlah Ayat

2-3

6. Perubahan Level

Durasi

$\underline{30-30}$

$(=0)$

$\underline{1-1}$

Frekuensi

$$
(=0)
$$

Jumlah Ayat

$\underline{\text { Stabil }}$

4-7

$\begin{array}{ll}\frac{60-60}{(=0)} & \frac{30-30}{(=0)} \\ \frac{1-2}{(+1)} & \frac{1-1}{(=0)} \\ \frac{4-7}{(+3)} & \underline{3-5} \\ & (+2)\end{array}$


Melalui penerapan intervensi, "YS" memperoleh beberapa perubahan berpikir dalam memandang kegiatan menghafal. Perubahan tersebut yaitu pada saat kegiatan menghafal yang sebelumnya dianggap sulit menjadi hal yang mudah, dari yang membosankan menjadi sesuatu yang menyenangkan. Untuk kecenderungan arah dengan trend "mendatar" artinya bahwa data hasil pengukuran dan pengamatan pada suatu kondisi tidak mengalami peubahan. Hal ini terjadi pada aspek lamanya menghafal/durasi, tidak ada perubahan data yang terjadi pada ketiga kondisi. Ketiga kondisi tersebut diberikan perlakuan dengan waktu yang sama di setiap fasenya, kemudian ditingkatkan durasinya pada fase intervensi.

Kedua, data hasil kecenderungan stabilitas menunjukkan bahwa data yang diperoleh pada ketiga kondisi dari aspek lamanya menghafal/durasi yaitu mencapai $100 \%$. Hal ini artinya bahwa data tersebut berada dalam kondisi stabil. Berbeda pada aspek jumlah ayat yang dihafal dan frekuensi menghafal, terdapat data yang menunjukkan hasil yang tidak stabil (variabel) terutama pada fase intervensi dan hasil. Kestabilan sebuah data bukan berati kegagalan suatu intervensi, stabilitas data di atas hanya melihat seberapa stabilkah perilaku menghafal juz'ama "YS". Hal yang perlu diketahui bahwa kestabilan perilaku setiap orang sangat dipengaruhi oleh beragam faktor. Seperti: lingkungan tempat tinggal, faktor dalam diri (semangat), lingkungan pertemanan, dan dukungan orang tua.

Data yang tidak stabil berarti menunjukan bahwa kondisi cara menghafal anak juga tidak stabil yang sangat erat kaitannya dengan faktor-faktor di atas. Hal ini bukanlah suatu masalah, namun suatu kewajaran semata. Perubahan dalam diri "YS" juga perlu diperhatikan terutama yang berhubungan dengan motivasi dan rasa semangat anak untuk belajar menghafal. Perubahan semangat ini terjadi pada saat peneliti melakukan intervensi. Subjek "YS" terkadang sangat semangat untuk menghafal, tapi di lain waktu, terkadang anak sangat enggan menghafal terutama ketika ada temannya yang mengajak main. Dalam menentukan berhasil atau tidaknya suatu intervensi, kita perlu melihat perubahan yang terjadi di Hasil (A2). Setidaknya ada perubahan positif yang terjadi pada fase hasil (A2) jika dibandingkan dengan fase baseline (A1) dari aspek frekuensi menghafal. Begitu pun sebaliknya, dengan aspek jumlah ayat yang dihafal ada perubahan positif yang terjadi dari fase baseline ke fase intervensi. Kualitas ayat (panjang/pendek ayat) sangat berpengaruh dalam proses mengahafal ayat. Ayat yang cukup panjang, perlu waktu dan frekuensi yang cukup banyak dibandingkan dengna ayat yang pendek.

Komponen analisis dalam kondisi yang berkaitan dengan kecenderungan jejak data bahwa data hasilnya memiliki kesamaan dengan data hasil kecenderungan arah. Begitu juga dengan data hasil pada level stabilitas dan rentang sama halnya dengan data yang diperoleh dari hasil perhitungan stabilitas. Ketiga, untuk melihat besarnya perubahan antara dua data maka dilakukan analisis perubahan level. Perubahan level pada setiap fase mengindikasikan bahwa setiap sesi dalam fase tersebut apakah cenderung membaik, memburuk, atau tidak adanya perubahan.

Berdasarkan Tabel 2, menunjukkan bahwa perubahan level yang terjadi pada aspek durasi menghafal mencapai nilai 0 , artinya bahwa pada setiap fase untuk mengamati perilaku menghafal juz'ama tidak mengalami perubahan. Berbeda dengan perubahan level yang terjadi pada aspek frekuensi menghafal dan jumlah ayat yang dihafal. Kedua aspek tersebut menunjukkan perubahan level yang meningkat. Aspek frekuensi mengalami kenaikan nilai sebesar $(+1)$ pada fase intervensi sedangkan aspek jumlah ayat yang dihafal menaik pada fase intervensi dan fase hasil dengan masing-masing nilai $(+3)$ dan $(+2)$. Kedua kondisi tersebut dapat dikatakan membaik pasca diberikannya intervensi.

Analisis antarkondisi ini digunakan untuk membandingkan data hasil yang diperoleh dari satu fase ke fase berikutnya, misalnya antar 
fase baseline (A1) dengan fase intervensi (B). Dalam penelitian ini, perbandingan dilakukan antara fase baseline (A1) dan fase intervensi (B) dengan kode B/A1 sedangkan fase intervensi (B) dengan fase hasil (A2) diberikan kode A2/B. Komponen yang dianalisis antara lain melihat jumlah variabel yang diubah, perubahan arah dan efeknya, perubahan stabilitas, perubahan level, dan data overlap. Berikut Tabel 3 merupakan rangkuman hasil analisis antarkondisi.
Jumlah variabel yang diubah dalam penelitian ini terdiri dari tiga variabel antara lain aspek lamanya menghafal/durasi, jumlah perilaku menghafal yang dilakukan dalam sehari/frekuensi, dan jumlah ayat yang dihafal. Ketiga aspek di bawah ini merupakan satu rangkaian yang akan diukur dan diamati oleh peneliti dalam melihat peningkatan perilaku menghafal juz'ama "YS".

Tabel 3

Rangkuman Hasil Analisis Antarkondisi

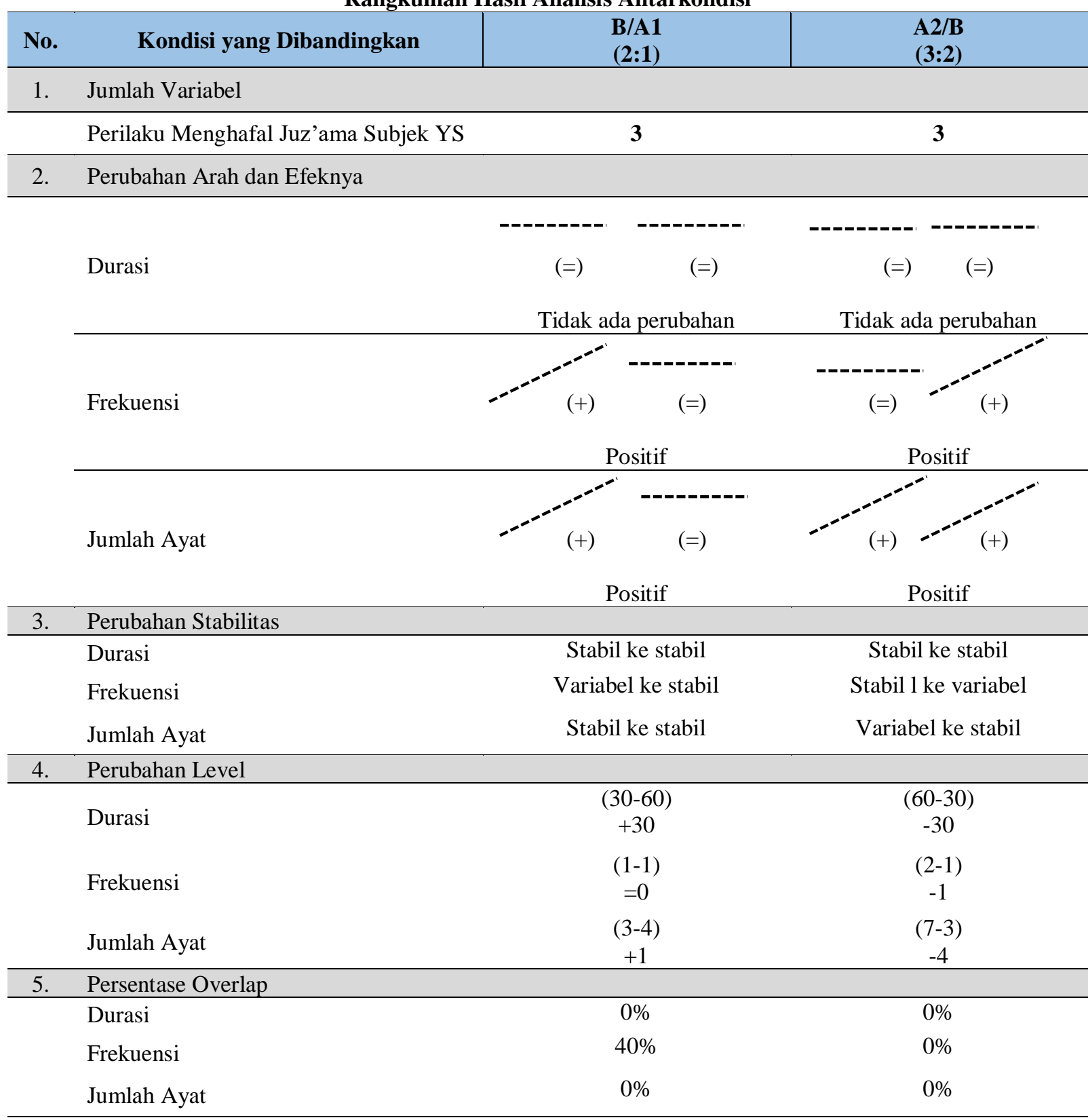


Data perubahan arah dan efeknya dengan membandingkan antar kondisi bertujuan untuk mengamati target perilaku yang akan diubah dari satu fase ke fase berikutnya. Untuk aspek yang berkaitan dengan durasi menghafal, perubahan arahnya menunjukkan hasil yang mendatar. Trend yang mendatar ini artinya bahwa perbandingan dua kondisi antara B/A1 dan A2/B tidak adanya perubahan. Namun, kedua aspek yang bertujuan untuk melihat frekuensi menghafal dalam sehari memiliki efek positif dengan perubahan arah meningkat atau menaik. Perubahan arah yang meningkat tersebut terjadi pada kedua kondisi yaitu antara kondisi baseline dengan kondisi intervensi serta kondisi intervensi dengan kondisi hasil.Selanjutnya, perbandingan perubahan stabilitas pada aspek durasi menghafal untuk kedua perbandingan kondisi baik B/A1 dan A2/B memiliki hasil "stabil ke stabil". Hasil tersebut menunjukan bahwa "YS" mampu melakukan kegiatan menghafal secara stabil dan teratur. Itu berarti "YS" memiliki tingkat konsentrasi yang bagus meskipun dalam jangka waktu yang berbeda-beda.

Perubahan level pada perilaku menghafal juz'ama "YS" untuk ketiga aspek yang menjadi fokus pengamatan dan pengukuran memiliki nilai yang berbeda. Perubahan level untuk perbandingan kondisi antara B/A1 dan A2/B pada aspek durasi memiliki makna bahwa kemampuan menghafal "YS" mengalami peningkatan. Meskipun dilihat dari data hasil perubahan level pada perbandingan kondisi A2/B mendapatkan data point 60-30 dengan selisih (-30), artinya bahwa kemampuan menghafal "YS" dilihat dari aspek durasi/ lamanya waktu menghafal mengalami penurunan.

Perbandingan kondisi antara B/A1 dan A2/B pada aspek frekuensi menghafal dalam sehari memiliki nilai selisih sebesar 0 dan $(-1)$. Nilai tersebut memiliki arti bahwa tidak terjadi perubahan pada perbandingan kondisi B/A1 serta mengalami penurunan pada perbandingan kondisi A2/B. Selanjutnya, data hasil perubahan level pada aspek banyaknya jumlah ayat yang dihafal menunjukkan data point 3-4 dengan selisih (+), artinya bahwa perbandingan kondisi tersebut mengalami peningkatan. Sedangkan pada perbandingan kondisi A2/B mengalami penurunan dengan selisih nilai (-4).

Komponen analisis antarkondisi yang terakhir yaitu dengan melihat ada atau tidaknya data yang tumpang tindih diantara perbandingan kondisi B/A1 dan A2/B. Data yang tumpang tindih ini mengindikasikan bahwa data tersebut memiliki kesamaan pada kedua kondisi dan tidak mengalami perubahan. Data hasil pengukuran dan pengamatan dalam suatu penelitian dikatakan mengalami overlap, apabila nilai presentasenya lebih dari $90 \%$. Berdasarkan tabel 4.27 di atas, bahwa data persentase overlap perbandingan kondisi B/A1 dan A2/B memiliki nilai 0\% pada kedua aspek yaitu durasi/lamanya waktu menghafal dan jumlah ayat yang dihafal.

Data persentase overlap yang mencapai $0 \%$ tersebut menunjukkan bahwa tidak adanya data yang tumpang tindih diantara perbandingan dua kondisi. Sedangkan data persentase overlap perilaku menghafal juz'ama pada aspek frekuensi menghafal "YS" dalam sehari mencapai $40 \%$, artinya bahwa sebagian ada sebagian data yang sama atau tumpang tindih antara fase baseline dengan fase intervensi. Namun, hal ini tidak sepenuhnya bahwa data tersebut mengalami overlap, masih ada perubahan yang terjadi meskipun hanya sebesar $60 \%$.

\section{Simpulan}

Berdasarkan hasil penelitian dapat disimpulkan bahwa kesulitan dalam menghafal juz'ama "YS" disebabkan oleh cara berpikir "YS" yang salah dalam memandang kegiatan menghafal. Hal ini menjadi alasan utama bagi "YS" untuk berperilaku malas-malasan, tidak peduli, acuh, dan bolos sekolah atau tidak masuk sekolah pada setiap jam pelajaran juz'ama. Intervensi yang digunakan untuk menangani permasalahan di atas yaitu dengan terapi perilaku kognitif. Melalui pendekatan terapi ini, peneliti berhasil mengubah cara berpikir "YS" terhadap kegiatan menghafal, sehingga 
hal ini berpengaruh pada perilaku yang ditampilkannya.

Pendekatan terapi perilaku kognitif adalah suatu pendekatan dalam praktik pekerjaan sosial yang memandang bahwa perilaku dapat dipengaruhi oleh pikiran dan perasaan seseorang; perilaku malas-malasan, tidak peduli, dan acuh "YS" terhadap tugas hafalan juz'ama muncul dikarenakan cara pandang "YS" dalam memaknai hafalan yang dianggapnya sulit dan membosankan.

Penerapan terapi perilaku kognitif ini menunjukkan hasil yang efektif dalam meningkatkan perilaku menghafal juz'ama "YS" baik dari segi durasi menghafal, frekuensi menghafal, dan jumlah ayat yang dihafal (kuantitas ayat). Perubahan yang dicapai oleh subjek "YS" berkaitan dengan perubahan cara berpikir "YS" dalam memandang tugas hafalan juz'ama menjadi suatu hal yang menyenangkan dan mudah. Teknik yang digunakan untuk mengubah cara berpikir"YS" yaitu dengan menggunakan teknik selftalk.

Perubahan positif yang terjadi pada subjek "YS" tersebut dikarenakan "YS" telah menyadari bahwa kegiatan menghafal itu merupakan tugasnya sebagai pelajar sehingga wajib untuk dilakukan agar "YS" dapat lulus tanpa syarat. Selain itu juga, peran peneliti yang selalu memberikan motivasi kepada subjek "YS" untuk belajar menghafal secara bertahap. Sedangkan untuk perubahan perilaku, peneliti menggunakan teknik token ekonomi.

Teknik token ekonomi berhasil meningkatkan perilaku menghafal juz'ama "YS", hal ini dikarenakan hadiah token yang berfungsi untuk menstimulasi "YS" menghafal juz'ama merupakan token yang diinginkan berdasarkan kebutuhannya. Token yang berhasil dikumpulkan oleh subjek "YS" selama lima (5) sesi fase intervensi yaitu sebanyak 40 bintang. Token bintang tersebut ditukarkan dengan hadiah berupa alat tulis sekolah, Bahkan untuk mendapatkan hadiah tersebut, peneliti mengajak wisata belanja langsung ke toko peralatan sekolah sehingga subjek "YS" dapat memilih sendiri alat tulis sekolah berdasarkan kebutuhannya.

Hasil temuan dalam penelitian ini menjadi dasar bagi peneliti merekomendasikan kepada pihak-pihak terkait sebagai berikut: 1) Subjek "YS": Subjek "YS" dapat mempertahankan hasil yang telah dicapai selama kegiatan intervensi berlangsung; Menjaga terus semangat belajarnya agar "YS" mampu menghafal tugas hafalan dalam mata pelajaran lain; Membatasi kegiatan bermainnya baik dengan teman di lingkungan tempat tinggal maupun teman sekolahnya. Pembatasan jadwal bermain ini bertujuan agar "YS" dapat meluangkan waktu untuk belajar di rumah; Subjek "YS" perlu berlatih untuk membuang pikiran-pikiran negatif yang dapat menghambat "YS" dalam melakukan aktivitas menghafal. 2) Keluarga "YS". Memberikan perhatian dan dukungan terhadap pendidikan "YS; Meningkatkan aktivitas belajar "YS" baik di sekolah dan rumah sehingga perilaku negatif "YS" seperti tidak masuk sekolah atau bolos sekolah agar dapat terkontrol dengan baik. 3) Sekolah "YS". Pihak sekolah perlu melakukan pengawasan dan pendampingan langsung terhadap subjek "YS"; Menyelenggarakan kegiatan belajar tambahan bagi siswa yang mengalami kesulitan dalam menghafal juz'ama, seperti yang dialami oleh "YS"; Guru yang bersangkutan dapat memberikan perhatian kepada siswa yang mengalami masalah dalam menghafal materi juz'ama. dengan cara membimbing dan mengajarkan setiap hafalan yang sulit dihafalkan oleh siswa secara bertahap. 3) Peneliti/Praktisi. Peneliti perlu mengkaji lebih dalam mengenai konsep tentang terapi perilaku kognitif sebagai panduan dalam menentukan masalah subjek; Pemahaman yang matang tentang konsep terapi perilaku kognitif dapat membantu peneliti dalam menentukan terapi yang tepat untuk mengatasi masalah subjek penelitian; Terapi perilaku kognitif ini dapat diterapkan pada kasus lain yang mengalami masalah kognisi; Peneliti perlu memperhatikan batasan usia pada subjek penelitian, dikarenakan terapi perilaku kognitif ini memerlukan kemampuan kognisi 
seseorang untuk dapat berpikir secara rasional. 4) Penelitian Lanjutan. Penelitian ini dapat digunakan sebagai rujukan untuk melakukan penelitian selanjutnya baik dilihat dari segi penggunaan metodelogi, terapi, dan fenomena yang akan ditelitinya; Penelitian ini dapat dilanjutkan dengan subjek yang berbeda; Dukungan orangtua untuk ikut serta memantau aktivitas belajar anak selama di rumah perlu ditingkatkan sehingga fenomena tersebut dapat dijadikan sebagai bahan penelitian di masa mendatang

\section{Daftar Pustaka}

Abu Huraerah. 2006. Kekerasan terhadap Anak. Bandung: Nuansa.

Adi Fahrudin. 2012. Teknik Ekonomi Token dalam Pengubahan Perilaku Klien. https://www.academia.edu/3600191/Teknik Token Ekonomi dalam Pengubahan Perilaku. Diakses pada tanggal 10 Juni 2017.

Beck, Judith S. 2011. Cognitive Behavior Therapy: Basic and Beyond. New York: The Guilford Press.

Dalyono. 2007. Psikologi Pendidikan. Jakarta: PT. Rineka Cipta.

Irniyati S. Jurnal Peksos. 15/2 (2016) 216.

Juang Sunanto, dkk. 2006. Penelitian dengan Subjek Tunggal. Bandung: UPI Press.

Kasandra Oemarjoedi, A Kasandra. 2003. Pendekatan Cognitive Behavior dalam Psikoterapi. Jakarta: Kreativ Publishing.

Nono Sutisna, dkk. 2013. Pengubahan Perilaku dalam Pekerjaan Sosial. Bandung: STKS Press.

Peraturan Menteri Sosial Nomor 08 Tahun 2012 Tentang Pedoman Pendataan dan Pengelolaan Data Penyandang Masalah Kesejahteraan Sosial dan Potensi Sumber Kesejahteraan Sosial.

Sheafor, W Bradford and Charles R Horejsi. 2003. Techniques and Guidelines for Social Work Practice. Sixth edition. Pearson Education.

Sugiyono. 2012. Memahami Penelitian Kualitatif. Bandung: Alfabeta.

Undang-Undang Nomor 35 Tahun 2014 Perubahan dari Undang-Undang Nomor 23 Tahun 2002 Tentang Perlindungan Anak. 